\title{
Glass Beads, Markers of Ancient Trade in Sub-Saharan Africa: Methodology, State of the Art and Perspectives
}

\author{
Farahnaz Koleini ${ }^{1}\left(\mathbb{D}\right.$, Philippe Colomban ${ }^{2, * \mathbb{C}}$, Innocent Pikirayi ${ }^{1}$ and Linda C. Prinsloo ${ }^{3,4}$ \\ 1 Department of Anthropology and Archaeology, Faculty of Humanities, University of Pretoria, Pretoria, \\ Hatfield 0028, South Africa \\ 2 Sorbonne Université, CNRS, MONARIS UMR8233, 4 Place Jussieu, 75005 Paris, France \\ 3 School of Earth and Environmental Sciences, University of Wollongong, Wollongong, NSW 2522, Australia \\ 4 Evolutionary Studies Institute, University of the Witwatersrand, PO Wits 2050, South Africa \\ * Correspondence: philippe.colomban@sorbonne-universite.fr
}

Received: 5 May 2019; Accepted: 2 August 2019; Published: 6 August 2019

\begin{abstract}
Glass beads have been produced and traded for millennia all over the world for use as everyday items of adornment, ceremonial costumes or objects of barter. The preservation of glass beads is good and large hoards have been found in archaeological sites across the world. The variety of shape, size and colour as well as the composition and production technologies of glass beads led to the motivation to use them as markers of exchange pathways covering the Indian Ocean, Africa, Asia, Middle East, the Mediterranean world, Europe and America and also as chronological milestones. This review addresses the history of glass production, the methodology of identification (morphology, colour, elemental composition, glass nanostructure, colouring and opacifying agents and secondary phases) by means of laboratory based instruments (LA-ICP-MS, SEM-EDS, XRF, NAA, Raman microspectroscopy) as well as the mobile instruments (pXRF, Raman) used to study glass beads excavated from sub-Saharan African sites. Attention is paid to the problems neglected such as the heterogeneity of glass (recycled and locally reprocessed glass). The review addresses the potential information that could be extracted using advanced portable methods of analysis.
\end{abstract}

Keywords: trade; beads; glass; pigments; provenance; Africa; Asia; Mediterranean world

\section{Introduction: Overview of Glass Production History}

We present here the first review of research conducted on trade beads from African sites covered in the literature and discuss about all identification methods for morphology and colour, elemental and molecular composition, pigments and secondary phases. We first give a very brief historical overview of glass production, then review the analytical methods, particularly non-invasive techniques adapted to identify glassy silicates and colouring agents/pigments/opacifiers. The classification history of beads with emphasis on sub-Saharan bead sites is considered before reviewing the results obtained and the discussion of special cases such as local productions, European copies and heterogeneous glass. Additionally, some perspectives are also discussed.

The first long distance trade in obsidian, a natural hard and brittle volcanic glass, which fractures with very sharp edges and is used to make cutting and piercing tools, was established during the Neolithic times [1,2]. The trade in synthetic glass objects and especially glass beads is not that old but has covered long distances, especially around and through the Indian Ocean. Since the beginning of the first millennium AD, the Indian Ocean was organized into a place around which the first world trade system was built, mostly with the assistance of monsoon winds [3,4], connecting the Near/Middle East, India, South Asia, China and Africa [3-5]. European merchants had commenced trading beads to 
Africa from the 15th century AD onwards. European glass beads were also exported to America as early as the 16th century AD [6-8].

The production of most historic glasses was obtained by reducing the melting temperature of silica (sand) through adding fluxing (sodium-, potassium- or lead-rich compounds) and stabilizing (calcium or aluminium based compounds) agents to form a non-crystalline solid that is often transparent. This technique was first mastered to make glazed artefacts around 5000-4000 BC [9] and the first synthetic glass, or more precisely a coloured incompletely molten material was made in Egypt, Mesopotamia and the Indus Valley circa 2000 BC to replace semi-precious stones and gems [10-12]. From about $1500 \mathrm{BC}$, transparent glass artefacts had been produced in the Levant, Crete and Egypt with a colour palette which was gradually broadened until $1200 \mathrm{BC}$ when political unrest led to a dramatic break in glass production [13]. New achievements in glass making had to wait until the 9th century BC, when the production of an almost colourless glass commenced in Syria and Cyprus $[14,15]$ and an upgraded moulding technique made it possible to achieve new complex shapes and designs [16]. Around $200 \mathrm{BC}$, Roman glassmakers developed the blowing technique and the production of glass artefacts became a heavy industry around $50 \mathrm{BC}[11,15]$.

Alexandria (Egypt), Sidon (Lebanon), Belus River (Levant), Campania and Rome (Italy) as well as Gaul (France) are mentioned as the most important industrial centres in Pliny the Elder's texts [17]. The most famous artefacts are enamelled glasses such as those from the Begram Ptolemaic Treasure [18] dated from the Roman to the early Byzantine period [19]. Then, the Normandy Court in Sicilia continued the production of complex enamelled objects [20] which developed during the Fatimid and Mamluk dynasties [21]. Enamelling and gilding declined in the Near Eastern countries at the end of the Middle-Ages as a direct consequence of the decline of Islamic influences following the sack of Damascus by the Mongols and of Byzantium by the Crusaders [22]. The golden age of Venetian glass thus started [23,24] after the Byzantine craftsmen had developed Venetian glass production [11]. The expertise of Venetian glassmakers reached its height in the 16th century when Murano workshops were the first to produce not only cristallo (rock crystal-like) glass, but also more complex lattimo (milky glass), aventurine glass and millefiori (glass with complex coloured design) $[9,11]$.

A decentralisation of glass production centres occurred during the Middle-Ages in western and northern European countries. Cologne, Leuven, Namur, Amiens and Beauvais then became important sites [25]. By the 16th century, Façon de Venise glass objects with the same transparency as original Venetian cristallo started to be produced in Holland [9]. Then, new types of clear, lead-based glasses were introduced during the 17th century. In England, Ravenscroft discovered the advantages of lead-based glass (crystal and flint glass) with a high optical index and pliability. The so-called crystal and flint glasses were made of high purity raw materials [26,27]. At the same time, Bohemian glassmakers prepared another kind of lead-based glass, richer in potassium and calcium which made the enamelling process easier [28]. Lead glass became also popular with Dutch glass engravers. Finally, the implementation of press-moulding in the USA (ca. 1825), transfer painting and acid-etching as well as new colouring agents broadened the variety of glass [26,29].

Glass production in southern India, Thailand, Vietnam, the Philippines and China seems to have started 3000 years ago [30-33]. Arikamedu is considered as the main and oldest Indian bead making site dating to a few centuries BC [5,34]. Its old name Virampatnam has been identified with the Pôdouke Emporion mentioned in the ancient texts of Ptolemy and the Periplus Maris Erythraei (namely "Trek in Red See", an ancient travel Greek book) [5]. Other ancient production sites are Mantai (old name Modutti) in Sri Lanka, Oc éo (Kattigara, Funan Kingdom, now southern Vietnam) as also mentioned in Ptolemy's Geography, Khlong Thom in Thailand and Kuala Selinsing in Malaysia. In China, the glass paste/glassy faience production dates from the Western Zhou Dynasty ( 1000 BC), but glass production was mainly developed during the Warring States Period and then the Eastern Han Dynasty (around the 4th century BC) in the provinces of Xingiian, Shandong, Henan, Guangdong and along the Yangtze River [33]. Two types of lead-based glass were produced using barium, potassium or sodium as the other fluxing agents [35]. Glass production in central Vietnam is associated with 
the Sa Huynh culture (the first millennium BC) [5] due to the development of firing techniques [36]. Although ancient glass production in Europe and the Mediterranean world is archaeologically well documented $[9,11,15,22,26]$, it is still a work in progress for Asian countries [35,37].

\section{Glass Bead Research}

Glass objects differ in their shape because of aesthetic and cultural/commercial constraints. Consequently, the morphology of a glass object can be a criterion for dating and sourcing. Beadmaking, together with stone tools and rock art, are among the first examples of humankind's creativity. The first beads, dating from more than 100,000 years ago, were made by piercing shells [38,39]. After that, holes were drilled into polished or natural stones (e.g., steatite) and gems (e.g., carnelian). Glazed stone and synthetic faience/glassy paste were used in the early kingdoms of Mesopotamia and Egypt. The preservation of glass beads is rather good and for instance, Francis [5] was the first to attempt tracing Asia's Indian Ocean trade by identifying beads and their production centres. His work was recently revisited in this regard [4,40-44].

The first glass beads were made by winding glass paste around a metal rod [45]. An improved mastering of glass melting techniques and understanding of viscosity properties of glass led to the manufacturing of tubes which resulted in a large variety of sizes and shapes when cut into beads. The moulding technique is ancient but was developed further during the Industrial Revolution, together with the spinneret technique $[9,26]$.

Even though many protocols (see below this section) to investigate the provenance of glass artefacts have been developed $[5,9,17,46]$, the multifaceted composition of a glass batch (summarized in Figure 1 and Table 1) and the complex reactions which occur during melting, together with all aspects introduced through recycling of especially coloured glasses, make the identification of historical sources difficult. In some cases, the elemental composition of a given type of raw material or a specific glass recipe can be used. Alternatively, multivariate statistical analysis such as Principal Component Analysis and hierarchical clustering methods can be used to identify the correlations/relationships between different artefacts [44,47].

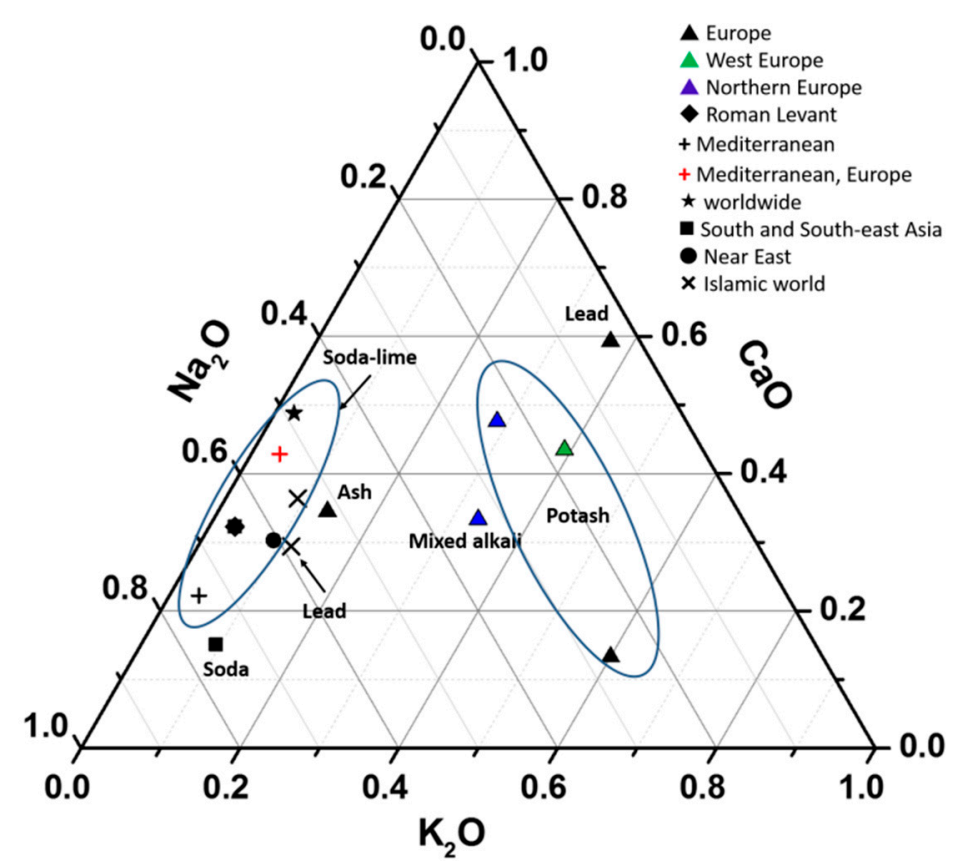

Figure 1. Variety of the glass flux compositions expressed in the $\mathrm{Na}_{2} \mathrm{O}-\mathrm{K}_{2} \mathrm{O}-\mathrm{CaO}$ relative ratio (for references see Table 1). 
From about the 5th century BC to around the 8th century AD, soda-lime glass, as typical Roman glass, were being produced in the Mediterranean area using natron, a sodium carbonate-rich mineral (trona) deposit collected from the Levant/Near East salt lakes [9,46,48-52]. Low potassium, magnesium and phosphorus levels are characteristic of this glass (Table 1). The sands of River Belus, between Haifa and Acre in present day Israel, have been widely cited since Pliny the Elder, as the most important source [52]. Pliny had already recognized the importance of shells which is a calcium-rich material, present in the sand. Venetian glaziers used high purity silica such as quartz, chert/flint pebbles which produced the optical quality of cristallo artefacts $[9,15,53]$. Different sub-types are recognised from their minor elements and variation in impurities $[54,55]$ (Table 1$)$.

The use of raw materials from a specific region and specific recipes for the production of glass influence the composition of a particular glass object $[52,54,56]$. From around the 8 th century AD to the Middle-Ages, halophytic plant ashes replaced natron as a flux in the Mediterranean world and consequently potassium, magnesium and phosphorus levels were higher in glasses produced after the 8th century [9]. However, glass recycling is very common which results in intermediate compositions. In Western Europe, continental plant ashes (beech, oak, bracken but also seaweed) rich in potassium were used to produce "forest" glass to be later replaced by glass made from imported Spanish Alicante soda ashes which were also produced in Sicily, south of France and Carthage in North Africa [57]. The use of potash-rich fluxes continued till the 19th century AD. In England, kelp ash was used as the source of potash flux [57]. Industrial soda was also in use by the end of the 18th century, first produced using the 'Leblanc' method and then with the Solvay process after 1861 [58-61]. As a consequence of the introduction of the Solvay process, glass manufactured after 1861 is characterized by high amounts of sodium and low levels of impurities.

Table 1. Glass types and main characteristics with their origin/period.

\begin{tabular}{|c|c|c|c|c|c|c|c|c|c|}
\hline \multirow[t]{2}{*}{ Glass Type } & \multirow[t]{2}{*}{ Sub-Groups } & \multicolumn{5}{|c|}{ Average Oxide Content (wt $\%$ ) } & \multirow[t]{2}{*}{$\begin{array}{c}\text { Expected } \\
\text { Alkali Source }\end{array}$} & \multirow[t]{2}{*}{$\begin{array}{c}\text { Period } \\
\text { (Centuries) }\end{array}$} & \multirow[t]{2}{*}{ Expected Origin } \\
\hline & & $\mathrm{Na}_{2} \mathrm{O}$ & $\mathrm{K}_{2} \mathrm{O}$ & $\mathrm{CaO}$ & $\mathrm{MgO}$ & $\mathrm{PbO}$ & & & \\
\hline \multirow{4}{*}{ Soda } & Low Al & $13-20$ & $0.4-1.5$ & $2-9$ & $0.4-2$ & & & from 2nd c. AD & \multirow{2}{*}{$\begin{array}{c}\text { Middle East, South } \\
\text { Asia, South-East } \\
\text { Asia }[5,56]\end{array}$} \\
\hline & \multirow{2}{*}{$\begin{array}{c}\text { High Al } \\
\left(\mathrm{Al}_{2} \mathrm{O}_{3}: 4-10 \%\right)\end{array}$} & \multirow[t]{2}{*}{$15-20$} & \multirow{2}{*}{$1.5-2.5$} & \multirow[t]{2}{*}{$2-4$} & \multirow{2}{*}{\multicolumn{2}{|c|}{$0.2-1$}} & \multirow[t]{2}{*}{$?$} & $\begin{array}{c}\text { from 1st } \\
\text { c. BC-6th c. AD }\end{array}$ & \\
\hline & & & & & & & & 9th-19th c. AD & South Asia $[34,56]$ \\
\hline & $\begin{array}{l}\text { Venetian cristallo, } \\
\text { Façon de Venise }\end{array}$ & $12-15$ & $2-4$ & $4-10$ & $1-3$ & & Ashes & $\begin{array}{l}\text { 15th-18th } \\
\text { c. } \mathrm{AD}\end{array}$ & Europe [54] \\
\hline \multirow{7}{*}{ Soda Lime } & Low $\mathrm{Al}$, high $\mathrm{Mg}$ & $8-20$ & $0-3$ & $3-10$ & $2-10$ & & Plant ashes & $\begin{array}{l}\text { from } 15 \text { th-8th } \\
\text { c. BC }\end{array}$ & Near East [22] \\
\hline & Low $\mathrm{Al}$, low $\mathrm{Mg}$ & $13-20$ & $0-1$ & $5-10$ & $0-1$ & & Natron & $\begin{array}{c}\text { from 8th } \\
\text { c. BC-3rd c. AD }\end{array}$ & $\begin{array}{l}\text { Roman Levant } \\
\left(\text { no Sb }_{2} \mathrm{O}_{3}\right)[48]\end{array}$ \\
\hline & $\begin{array}{c}\text { Low } \mathrm{Al} \text {, low } \mathrm{Mg} \text {, } \\
\text { high } \mathrm{Sb}\end{array}$ & $15-20$ & $0-1$ & $4-6$ & $0-1$ & & Natron & 1 st-3rd c. AD & $\begin{array}{l}\text { Mediterranean } \\
\text { area [46] }\end{array}$ \\
\hline & High $\mathrm{Fe} / \mathrm{Mg}$ & $16-20$ & $0-1$ & $5-10$ & $1-2$ & & Natron & 3rd-5th c. AD & \multirow{2}{*}{$\begin{array}{l}\text { Mediterranean } \\
\text { area, Europe [46] }\end{array}$} \\
\hline & Levantine glass & $10-15$ & $0-1$ & $8-12$ & $0-1$ & & Natron & 5th-8th c. AD & \\
\hline & $\begin{array}{l}\text { High Mg early } \\
\text { Islamic glass }\end{array}$ & $10-18$ & $1-3$ & $6-12$ & $3-7$ & & $\begin{array}{l}\text { Natron and } \\
\text { Plant ashes }\end{array}$ & 9th-10th c. AD & Islamic world [22] \\
\hline & Modern & $10-20$ & $0-1$ & $10-20$ & $0-1$ & & Synthetic soda & 19th c. AD & Worldwide [59] \\
\hline \multirow{5}{*}{ potash } & Low Mg, high $\mathrm{K}$ & $0-8$ & $8-18$ & $0-4$ & $0-1$ & & Plant ashes & Bronze Age & Europe [9] \\
\hline & High Al & & & & & & & from 1st c. BC & $\begin{array}{c}\text { Vietnam, South } \\
\text { China }[30,33]\end{array}$ \\
\hline & Medium Al & & & & & & & & South Asia [30] \\
\hline & $\begin{array}{c}\text { High K } \\
\text { European Glass }\end{array}$ & $0-8$ & $8-18$ & $6-20$ & $0-5$ & & Plant ashes & from 8th c. AD & West Europe [57] \\
\hline & $\begin{array}{l}\text { High lime, } \\
\text { low Alkali }\end{array}$ & $<10$ & $<12$ & $15-20$ & $0-1$ & & $\begin{array}{l}\text { Plant ashes } \\
\text { (oak) }\end{array}$ & $\begin{array}{l}\text { 15th-17th } \\
\text { c. AD }\end{array}$ & $\begin{array}{c}\text { Northern } \\
\text { Europe [57] }\end{array}$ \\
\hline
\end{tabular}


Table 1. Cont.

\begin{tabular}{|c|c|c|c|c|c|c|c|c|c|}
\hline \multirow[t]{2}{*}{ Glass Type } & \multirow[t]{2}{*}{ Sub-Groups } & \multicolumn{5}{|c|}{ Average Oxide Content (wt $\%$ ) } & \multirow[t]{2}{*}{$\begin{array}{c}\text { Expected } \\
\text { Alkali Source }\end{array}$} & \multirow[t]{2}{*}{$\begin{array}{c}\text { Period } \\
\text { (Centuries) }\end{array}$} & \multirow[t]{2}{*}{ Expected Origin } \\
\hline & & $\mathrm{Na}_{2} \mathrm{O}$ & $\mathrm{K}_{2} \mathrm{O}$ & $\mathrm{CaO}$ & $\mathrm{MgO}$ & $\mathrm{PbO}$ & & & \\
\hline Mixed & Mixed Alkali Glass & $5-10$ & $5-10$ & 10 & $2-6$ & & $\begin{array}{l}\text { Plant ashes } \\
\text { (seaweed) }\end{array}$ & $\begin{array}{l}\text { 16th-17th } \\
\text { c. } A D\end{array}$ & $\begin{array}{l}\text { Northern } \\
\text { Europe [57] }\end{array}$ \\
\hline \multirow{5}{*}{ Lead } & High Ba & & & & & & & from 3rd c. BC & China [35] \\
\hline & High $\mathrm{Na}$ & & & & & & & from 1st c. AD & China [35] \\
\hline & High $\mathrm{Na}$ & & & & & & & from 2 nd c. BC & Roman [22] \\
\hline & $\begin{array}{l}\text { High-lead } \\
\text { Islamic glass }\end{array}$ & $8-10$ & $0-2$ & $4-5$ & $0-1$ & $30-40$ & $\begin{array}{l}\text { Natron and } \\
\text { Plant ashes }\end{array}$ & $\begin{array}{l}\text { 10th c. AD- } \\
14 \text { th c. AD }\end{array}$ & Islamic world [22] \\
\hline & $\begin{array}{c}\text { High-lead } \\
\text { medieval glass }\end{array}$ & $0-1$ & $3-10$ & $4-16$ & $1-3$ & $20-65$ & Plant ashes & 8th-14th c. AD & Europe $[26,27]$ \\
\hline
\end{tabular}

Coloured glasses are more or less easily achieved by adding different colouring agents [61-65]. In primitive glass production, colour was due to the impurities in raw materials, mainly iron ions, but very early on, glaziers had tried to control colour [61,62]. The 'visible' colour arises from the wavelengths of light which were not absorbed by the material and detected by human vision. The wavelength absorption is due to (partially empty) electronic levels of some ions (so-called "chromophores"), namely the transition metal ions (3d level) and lanthanides/rare earth ions (4f level). Ions that are dissolved in the glassy silicate matrix $\left(\mathrm{Fe}^{2 / 3+}, \mathrm{Cu}^{2+}, \mathrm{Co}^{2+}, \mathrm{Cr}^{3+}, \mathrm{Mn}^{2 / 3 / 5+}, \mathrm{UO}_{2}{ }^{2+}, \mathrm{Pr}^{2+}\right.$ etc. $)$ colour the glass [63-66]. Alternatively, a phase hosting the above ions, either prepared separately as a pigment and dispersed in the glass precursor (mixing of "corpo" and "anima") or formed on cooling by precipitation can colour the glass [67].

The power of colouration achieved with pigments is much higher than that obtained with ions, but metal nanoparticles $\left(\mathrm{Cu}^{\circ}, \mathrm{Ag}^{\circ}, \mathrm{Au}^{\circ}\right)$ exhibit the highest colouration power [68]. Consequently, different methods are possible to obtain a given colour. For instance, white opacification can be obtained by at least ten different processes (Table 2) such as dispersion of (sub)micron bubbles, quartz grains, cassiterite, rutile, zircon, lead-calcium arsenate, calcium phosphate, calcite, fluorite or calcium antimonate particles $[62,63]$. Blue colour can be obtained with $\mathrm{Co}^{2+}$ ions, lapis lazuli grains, Egyptian blue (calcium copper silicate) and its Chinese barium homologue [69], cobalt silicate/aluminate, cobalt spinel or vanadium-doped zircon. Green colour can be prepared with $\mathrm{Cu}^{2+}$ ions or with chromium or nickel-based phases. An alternative technique is the mixing of yellow and blue chromophores/pigments [62,66]. Stable red colouring agents in a glass matrix are limited: hematite, hercynite, copper and gold nanoparticles are the unique colouring agents. However, it is difficult to use the metal nanoparticles as colouring agents due to their high power of colouration [68,70]. This changed with the discovery of cadmium sulphide-selenide solid solutions $\left(\mathrm{Cd}_{1-\mathrm{y}-\mathrm{z}} \mathrm{M}_{\mathrm{y}} \mathrm{S}_{1-\mathrm{x}} \mathrm{Se}_{\mathrm{x}} \mathrm{M}_{\mathrm{z}}\right)$, which were dispersed as nanoparticles in a glass matrix to give glass a vivid colour ranging from yellow to dark red [71].

Thus, the composition of glass (Table 1) and the nature of colouring agents (Table 2) can be specific to a period or production site and hence be considered as a post quem milestone. Such dating milestones can however be questioned due to the relatively small number of references and their representativeness, etc. Furthermore, glass recycling is possible and very early demonstrated as in the case of a Roman shipwreck discovery containing a cargo of broken blue glass [49]. Recycling of glass at production workshops leads to heterogeneous material with mean composition different from that of the reference groups. However, analysis of the microstructure can reveal the heterogeneity, for instance the fact that two or more types of glass grains are present (this is discussed further below). 
Table 2. Main opacifying and colouring agents used in glass.

\begin{tabular}{|c|c|c|c|c|c|}
\hline Colour & Elements & Phase & $\begin{array}{l}\text { Raman } \\
\text { Detection }\end{array}$ & First Use & Remarks \\
\hline \multirow{10}{*}{ White } & & bubbles & yes & & \\
\hline & $\mathrm{Si}$ & quartz $\left(\mathrm{SiO}_{2}\right)$ & yes & & \\
\hline & $\mathrm{Ti}$ & rutile, anatase $\left(\mathrm{TiO}_{2}\right)$ & yes & & \\
\hline & $\mathrm{Zr}$ & zircon $\left(\mathrm{ZrSiO}_{4}\right)$, zirconia $\left(\mathrm{ZrO}_{2}\right)$ & yes & 20th c. & \\
\hline & $\mathrm{P}$ & apatite $\left(\mathrm{Ca}_{3}\left(\mathrm{PO}_{4}\right)_{2}\right)$ & yes & Antiquity & bones \\
\hline & $\mathrm{Ca}$ & calcite $\left(\mathrm{CaCO}_{3}\right)$ & yes & & \\
\hline & $\mathrm{Sb}$ & antimonate $\left(\mathrm{CaSb}_{2} \mathrm{O}_{7}\right)$ & yes & Antiquity & \\
\hline & $\mathrm{Sb}$ & antimonate $\left(\mathrm{CaSb}_{2} \mathrm{O}_{6}\right)$ & yes & Antiquity & \\
\hline & Sn & cassiterite $\left(\mathrm{SnO}_{2}\right)$ & yes & 5th c. AD & \\
\hline & As & arsenate $(\mathrm{Ca}, \mathrm{Pb})_{1.5} \mathrm{AsO}_{4}$ & yes & 17th c. AD & \\
\hline \multirow{11}{*}{ Blue } & $\mathrm{Cu}$ & Egyptian blue $\left(\mathrm{CaCuSi}_{4} \mathrm{O}_{10}\right)$ & yes & $3000 \mathrm{BC}$ & \\
\hline & $\mathrm{Ba}, \mathrm{Cu}$ & Han blue $\left(\mathrm{BaCuSi}_{4} \mathrm{O}_{10}\right)$ & yes & 5th c. BC & \\
\hline & $\mathrm{Ba}, \mathrm{Cu}$ & Han violet $\left(\mathrm{BaCuSi}_{2} \mathrm{O}_{6}\right)$ & yes & 2nd c. BC & \\
\hline & $\mathrm{Cu}$ & dissolved $\mathrm{Cu}^{2+}$ & no & & $\begin{array}{l}\text { Turquoise in alkali } \\
\text { glass matrix }\end{array}$ \\
\hline & \multirow{2}{*}{$\mathrm{S}$} & lazurite $\left(\mathrm{Na}_{8}\left[\mathrm{Al}_{6} \mathrm{Si}_{6} \mathrm{O}_{24}\right] \mathrm{S}_{\mathrm{n}}\right)$ & yes & 1st c. BC & \\
\hline & & ultramarine & yes & 19th c. & \\
\hline & \multirow{4}{*}{ Co } & dissolved $\mathrm{Co}^{2+}$ & indirectly & & \\
\hline & & spinels $(\mathrm{Co}, \mathrm{Cr}, \mathrm{X}) \mathrm{AlO}_{4}$ & yes & 19th c. & \\
\hline & & olivine $\left(\mathrm{CoSiO}_{2}\right)$ & yes & 17th c. & \\
\hline & & cobalt oxide $\left(\mathrm{Co}_{3} \mathrm{O}_{4}\right)$ & yes & 19th c. & \\
\hline & $\mathrm{V}$ & zircon $\left(\mathrm{V}: \mathrm{ZrSiO}_{4}\right)$ & yes & 20th c. & \\
\hline \multirow{7}{*}{ Yellow } & $\mathrm{Fe}$ & dissolved $\mathrm{Fe}^{3+}$ & no & & \\
\hline & $\mathrm{Sb}$ & pyrochlore $\left(\mathrm{PbSb}_{2-\mathrm{x}} \mathrm{M}_{\mathrm{x}} \mathrm{O}_{7-\mathrm{d}}\right)$ & yes & 15th c. BC & Naples yellow \\
\hline & Sn & $\mathrm{Pb}_{2} \mathrm{Sn}_{1-\mathrm{y}} \mathrm{M}_{\mathrm{y}} \mathrm{O}_{4}$ & yes & Antiquity & \\
\hline & $\mathrm{U}$ & dissolved $\mathrm{UO}^{2+}$ & yes & & \\
\hline & $\mathrm{Pb}$ & $\mathrm{Pb}$ oxides & yes & Antiquity & \\
\hline & Sn & sphene $\left(\mathrm{CaSnSiO}_{5}\right)$ & yes & & malayite \\
\hline & $\mathrm{Zn}, \mathrm{Cr}$ & $\mathrm{ZnCrO}_{4}$ & yes & 19th c. & \\
\hline \multirow[t]{6}{*}{ Green } & $\mathrm{Cu}$ & $\mathrm{Cu}^{2+}$ dissolved & no & Antiquity & \\
\hline & $\mathrm{Cr}$ & $\mathrm{Cr}^{3+}$ dissolved & no & & \\
\hline & $\mathrm{Cr}$ & $\mathrm{Cr}_{2} \mathrm{O}_{3}$ & yes & 19th c. & \\
\hline & & $3 \mathrm{CaO} \cdot \mathrm{Cr}_{2} \mathrm{O}_{3} \cdot 3 \mathrm{SiO}_{2}$ & yes & 19th c. & $\begin{array}{l}\text { Victoria green, } \\
\text { malayite }\end{array}$ \\
\hline & $\mathrm{Cr}, \mathrm{Co}$ & spinels: $\mathrm{CoCr}_{2} \mathrm{O}_{4}, \mathrm{CoTiO}_{4}$ & yes & 19th c. & \\
\hline & & olivine $\left(\mathrm{NiSiO}_{4}\right)$ & yes & & \\
\hline \multirow[t]{3}{*}{ Red } & $\mathrm{Cu}$ & $\mathrm{Cu}^{\circ}$ & indirect & Bronze age & \\
\hline & $\mathrm{Fe}$ & hematite & yes & 15th c. & \\
\hline & $\mathrm{Au}$ & $\mathrm{Au}^{\circ}$ & indirect & 16th c. & \\
\hline
\end{tabular}




\section{Analytical Methods Used to Analyse the Glassy Matrix and Colouring Agents}

Recently, Janssens [9] compiled a review of all the techniques for analysing glass as previously made by Pollard and Heron [72]. It is, however, sometimes difficult to apply all the above-mentioned techniques on glass beads because of their size and limited possibilities of sampling. In many countries, modern ethics of archaeology prohibit destructive analyses and exportation of artefacts away from their sites. However, the number of beads found on-site can be very variable from a few items to more than 100,000 , as in the case of Mapungubwe Hill [73]. Analytical techniques of bead analysis have recently been reviewed by Bonneau et al. [6,74]. The most common techniques to analyse glass beads are optical microscopy (OM), scanning electron microscopy (SEM) and associated composition/structure measurement techniques (Energy Dispersive Spectroscopy—EDS), X-ray fluorescence (XRF), neutron activation analysis (NAA), laser ablation inductively coupled plasma mass spectrometry (LA-ICP-MS), and Raman microspectroscopy [75]. Three of these methods such as OM, pXRF and Raman are non-destructive, non-invasive and can be conducted with portable instruments [76].

\subsection{Optical Microscopy}

Macroscopic and microscopic optical observations can answer many questions regarding manufacturing techniques and use of the artefacts [77]. For instance, as noted by Bonneau et al. [74], bubbles and striations on the surface of drawn beads are elongated, while those in wound beads they tend to be round. Wound beads also exhibit wind marks that encircle the diameter. An examination of the ends of a bead may reveal battering which suggests their use in necklaces or bracelets. Finally, microscopic observation reveals the state of degradation of the glass. Optical microscopy magnification is limited to $\times 2000$.

\subsection{Scanning Electron Microscopy (SEM)}

The magnification and elemental characterization provided by scanning electron microscopy coupled with energy dispersive spectrometry (SEM-EDS) improve the examination of tool traces and the study of secondary phases which are evidence of the raw materials and the technology of production. The deposition of a very thin carbon film on the objects increases the quality of the images obtained. However, cutting a slice off the beads is generally required to get a representative view. Backscattered electron images are very useful to examine glass heterogeneity, as many beads are not made of homogeneous glass but of glass-ceramic, a mixture of glass and micro/nanocrystalline phases $[67,78]$.

A great advantage of SEM examination is the possibility to couple the instrument to an X-ray energy dispersive spectrometer (SEM-EDS or SEM-EDX) at the desired scale. The probed area can vary between a few $\mathrm{nm}^{2}$ to hundreds of $\mu \mathrm{m}^{2}$ and the detection of elemental composition can be achieved with a high accuracy level if glass standards are used to validate the procedure $[67,79,80]$. However, the heterogeneity of many glass beads should be considered and only the examination of a flat or convex section, instead of a rough surface, provides reliable data. Minor elements can be measured as well as traces. Error margins depend on the element and the amount present in the glass mixture as major (error $<5 \%$ ), minor or traces (error up to $20 \%$ ). It should be noted that the local heterogeneity can be higher in many cases.

\subsection{X-ray Fluorescence (XRF)}

X-ray fluorescence (XRF) and SEM-EDS both measure elemental composition but for XRF, the probed area is much larger (hundreds of $\mu \mathrm{m}^{2}$ to $\mathrm{mm}^{2}$ ) depending on the instrument and the distance between the instrument and the artefact. Sometimes a camera controls or selects the analysed area [81]. In this technique, $X$-rays are focused on the sample which is excited and generates new $X$-rays characterizing the elements present. The results are generated in the form of spectra, as in the case of SEM-EDS and appropriate calculations determine the composition, according to some given assumptions. Standard laboratory (fixed) instruments can detect elements from carbon to theoretically 
the end of the periodic table and the X-ray beam penetrates deeper into the sample (ca. $1 \mu \mathrm{m}$ for SEM-EDS; ca. 10-100 $\mu \mathrm{m}$ for XRF depending on the composition and energy). In the case of SEM-EDS, the limits of detection (LOD) depend on the chemical elements. To simplify, the typical LOD is about $0.1-2 \%$ oxide by weight for light elements and about 1 to $25 \mathrm{ppm}$ oxide by weight for heavy elements. Many traces are thus easily measured. In contrast to SEM-EDS, XRF analysis cannot really be quantitative without a flat surface and a comparison to glass standards with composition similar to that of the studied material.

An advantage of XRF is the existence of portable instruments which are much cheaper than laboratory based ones and therefore more available to archaeologists. However, the first problem with portable XRF instruments is that elements lighter than magnesium cannot be measured, but calculation and comparison with references can identify different types of glass [82-84]. The second problem with non-destructive XRF analyses with portable instruments on unprepared samples is the lack of flat (corrosion-free) surfaces and the difficulty to minimise the distance between the artefact and the instrument as well as keeping it constant. X-rays are absorbed/scattered by the air and when the control of the artefact-instrument distance is not possible, data should be normalised, using for instance the signal of silicon (common to most of the phases) or that intrinsic to the cathode of the instrument (Ag, Rh, etc.). A vacuum pump or helium gas injection eliminates most of the air and increases the reliability of the measurements at the same time decreasing the portability of the set-up. The comparison of the ratios of signal intensities of elements to identify raw materials and production technology is often more efficient than the comparison of elemental concentrations, provided by the instrument software. Multivariate statistical analysis is often essential.

XRF and SEM-EDS analyses are thus very useful in quantifying the chemical elements in glass, even in small proportions, and to define glass sub-groups which may be linked to production sites.

\subsection{Neutron Activation Analysis (NAA)}

The development of NAA techniques in the 1960s originated with the impetus of material science and contributed to that of archaeometric and provenance studies [74,75]. Samples are placed into a suitable irradiation facility and bombarded with neutrons, which creates artificial radioisotopes of the elements present. The artificial radioisotopes decay with the emission of gamma rays. The emissions are recorded using a gamma spectrometer and similar to SEM-EDS and XRF, each level of gamma-ray energy characterizes a specific element in the periodic table. As in the case of XRF, it requires standards for quantitative measurements of elements. One of the great advantages of NAA is that no sampling is generally required for small artefacts like beads. On the other hand, if the artefact is a composite like glass ceramics, the results will only reflect the mean composition. Unfortunately, the number of nuclear reactors offering NAA facilities has strongly decreased in the last decades and the technique whatever its interest, is now rarely used. Furthermore, the induced radioactivity can dictate that the sample has to be kept in isolation for months to a year before it can be considered as non-radioactive.

\subsection{Laser Ablation Inductively Coupled Plasma Mass Spectrometry}

For about twenty years now, laser ablation inductively coupled plasma mass spectrometry (LA-ICP-MS) has replaced NAA to produce accurate mean compositions of many materials $[34,85,86]$. A small part of the material, a $\sim 100 \mu \mathrm{m}$ diameter spot, is volatilized by a laser pulse and ionised. Then, a mass spectrometer separates and quantifies the atoms (and isotopes with advanced instruments) $[84,87,88]$. In many cases for accurate results, the technique requires that the amount of one of the chemical elements in the sample (an "internal standard", e.g., silicon) should be known, before it is analysed. It is a surface technique, so testing points need to be free of corrosion. A quick, initial laser ablation of the spot or the line to be analysed is often carried out to remove the surface layers of the samples. The potential measurement of the isotopes offers new tools for provenance identification. The limit of detection (LOD) is very low for many elements and thus, the composition of the volatilized matter is determined with high accuracy. However, the representativeness of the 
measurement can be questioned for many materials despite the high sensitivity of the technique. Data collected by XRF and EDS in combination with imaging techniques give a more representative view of the material enabling improved documentation and comparison of glass technology and origin.

\subsection{Laser Induced Breakdown Spectroscopy (LIBS)}

LIBS (Laser Induced Breakdown Spectroscopy) also involves volatilisation of a small volume of material in order to reach the non-corroded material but the elemental composition is determined from emission spectroscopy $[89,90]$. The development of this portable technique is recent and has not been used for beads to our knowledge [91].

\subsection{Raman Spectroscopy}

Raman spectroscopy is another analytical technique, which has recently been applied to glass artefacts. The so-called Raman Effect arises from the interaction of a laser beam, i.e., a monochromatic coherent light with the electron clouds of chemical bonds continuously distorted by atomic vibrations, or in other words the variation of the polarisability of chemical bonds. The scattered Raman spectrum forms a set of different peaks with the peak wavenumber position mainly depending on the atomic mass and interatomic bond forces. The number of peaks and polarisation depend on the symmetry of the chemical bond arrangement (the structure) and the intensity of local charge transfer (in reference to the conductivity at a very high frequency $\mathrm{THz}$ ).

Briefly, the Raman spectrum of a glassy silicate is composed of two massifs (broad peaks) with one centred at ca. $500 \mathrm{~cm}^{-1}\left(\mathrm{SiO}_{4}\right.$ tetrahedron bending modes) and the other at ca. $1000 \mathrm{~cm}^{-1}$ $\left(\mathrm{SiO}_{4}\right.$ tetrahedron symmetrical stretching modes), a broad "Rayleigh" wing below $100 \mathrm{~cm}^{-1}$ and the so-called Boson peak, arising from the contribution of librational and lattice modes below $300 \mathrm{~cm}^{-1}$. The contribution of other modes is not significant in a first approximation. The calculated ratio of the areas under both massifs respectively is known as the polymerization index $\left(I p=A_{500} / A_{1000}\right)$, which is related to glass nanostructure and thus to the processing temperature of glass [92]. Identification of the glass type (potash, lead-based, high lime-low alkali, soda and soda-lime glass) is possible from the visual measurement of the massif wavenumber maxima (see the next section). Thus, Raman spectroscopy is a relatively inexpensive and quick technique to obtain information from glass beads with the availability of portable instruments. As a scattering method, its great advantage is that no sampling or sample preparation is required. A potential problem with recording Raman spectra is fluorescence, another optical phenomenon much more intense than the Raman spectrum that can overlap with it, making its detection difficult.

\section{Bead Research in Sub-Saharan Africa}

We review here the studies used to identify glass bead technology, provenance and production date regarding beads excavated in Africa. The focus on sub-Saharan Africa is due to the large trade of beads in these countries and the high quantity of research conducted on excavated beads in the central and southern parts of the continent. For instance, analysis of the bibliography (almost exhaustive) compiled by the Society of Bead Researchers lists 243 articles that were published between 1981 and 2016 [93] (summarised in Table 3 based on locations in Africa). 
Table 3. A summary on number of published articles about glass beads found in Africa except Egypt and the east and west coast islands of Africa. Compiled by the Society of Bead Researchers [93].

\begin{tabular}{ccc}
\hline Location & Country (Number of Sites) & Percentage \\
\hline West Africa & $\begin{array}{c}\text { Ghana (13), Mauritania (9), Mali (7), Senegal (3), Burkina Faso } \\
\text { (2), Niger, Sierra Leone; Benin (2), Nigeria, (12), Guinea }\end{array}$ & $46 \%$ \\
\hline North Central Africa & Congo (4), Cameroon, Angola (4) & $7 \%$ \\
\hline Southern Africa & South Africa, Botswana \& Namibia (17), Zimbabwe (6) & $21 \%$ \\
\hline East Africa & Kenya, Uganda and Zanzibar (12), Ethiopia (7), Madagascar (3), & $26 \%$ \\
\hline
\end{tabular}

\subsection{Brief Overview on Methods of Classification}

Figure 2 shows the variety of size, shape and colour of beads excavated at different archaeological sites in Southern Africa (Botswana, South Africa and Zimbabwe) with occupation dates from around the 10th to 19 th centuries $\mathrm{AD}[78,82,83,94,95]$.

1 11

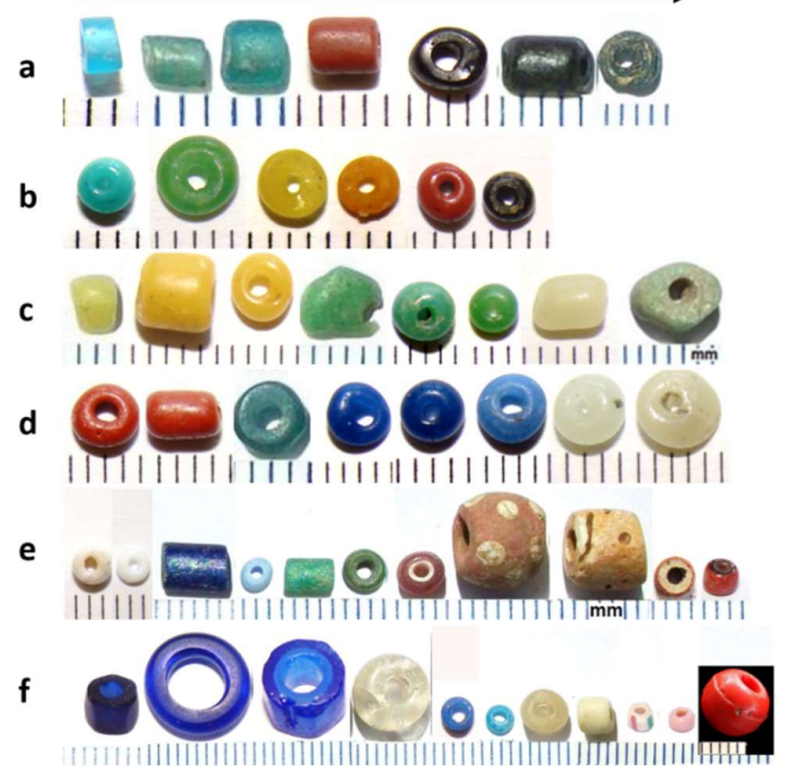

Figure 2. Bead selection illustrating the variety of shapes (tube, cylinder, oblate, etc.), diameter and colours. (a) K2-IP series (1-3), EC-IP series (4-7); (b) Mapungubwe Oblates (1-6) from Mutamba; (c) and (d) Khami-IP series; (e,f) European beads.

Scholars first attempted to classify the beads as a function of their morphology. The first classification system was proposed by Beck in 1937 and later refined by Malleret in 1949 and by Van Riet Lowe in 1955 [96-98]. New attempts were made by Kidd and Kidd [99], Van der Sleen [45] and Karklins [100] through the Society of Beads Researchers and others [101]. The first goal of these morphological classifications was the establishment of criteria which precisely described the shape and colour of the artefacts [102], regardless of the materials and technology used to produce them.

More recently in the Digital Archaeological Archive of Comparative Slavery [103], Decorse [104] discusses the potential to use beads as temporal markers in West African archaeology by drawing primarily on data obtained from the excavations at Elmina, Ghana. At the same time, Saitowitz [8] reviewed the classification terms used to describe beads by North American bead researchers and suggested that these could be used in future South African bead studies (see also $[105,106]$ ). Wood developed this approach on glass beads excavated from different sites that are dated to the 
8th-16th centuries AD in sub-Saharan Africa. Collaboration between Wood and Robertshaw's group for the compositional study of the same glass beads (e.g., those excavated from Chibuene, a 6th-17th century port in southern Mozambique) made it possible to link morphological and chemical classifications $[107,108]$. The composition and colour of glass trade beads from West Central Africa were studied by Rousaki et al. [109], Costa et al. [84] and Coccato et al. [110]. Recently, a review about glass/glass bead local (Ife-Ife) industries in Nigeria has been published [111]. However, almost the totality of glass beads seems (or are considered) to have been imported to Africa. However, careful Raman examination of a bead's microstructure by analysing many different spots or examination by optical microscopy may further reveal recycling or reprocessing. Table 4 lists the places where local production has been suspected or identified.

Table 4. Identified/expected local production of glass beads.

\begin{tabular}{ccccc}
\hline Type & Place & Date & Remarks & References \\
\hline Garden Roller & K2 Limpopo Valley, SA & K2 $(1100-1220)$ & $\begin{array}{c}\text { Moulds found with beads. Big beads } \\
\text { were made by sintering/melting } \\
\text { smaller imported ones }\end{array}$ & {$[107,112-114]$} \\
\hline Kiffa beads & Kiffa, Mauritania & 19th c. & Made from glass powder & {$[115,116]$} \\
\hline Bodom & Ghana Western Africa & 19th c. & Powder-glass & {$[5,117]$} \\
\hline Iyun, Segi & Ife, Nigeria & 12th-14th c. 18th c. & Grinding, powder-glass beads & {$[118]$} \\
\hline Ile-Ife, Nigeria & 11th-15th c. & $\begin{array}{c}\text { Glass cake, melting beads, } \\
\text { high lime-high alumina, high } \\
\text { lime-low alumina, soda-lime. }\end{array}$ & [119] \\
\hline $\begin{array}{c}\text { Light green } \\
\text { drawn bead }\end{array}$ & Basinghall (Botswana) & 1592-1648 & $\begin{array}{c}\text { Crucible production of high } \\
\text { lime-high alumina and low lime-high } \\
\text { alumina glass from } \\
\text { raw local materials. }\end{array}$ & [111] \\
\hline Blue beads & Carthage/Utica & 1st c. & $\begin{array}{c}\text { Inhomogeneous glass made by } \\
\text { sintering soda, mixed alkali and } \\
\text { potash glass. }\end{array}$ & [78] \\
\hline
\end{tabular}

\subsection{Bead Type Identification for Sub-Saharan Africa}

Wood's classification system for beads imported into South Africa before the European contact has become the first step for archaeologists to classify beads at any site in sub-Saharan Africa. Figure 3 summarizes Wood's classification of sub-Saharan glass trade beads based on morphology: eight series of beads are recognized and named according to the site where it was first studied and for which radiocarbon dates are available [43,120-123] (Figure 4). The great variation of colour that changed with time is obvious. The oldest series (7th-8th centuries) is linked to Chibuene, an Indian Ocean port located on the African coast of Mozambique, between the Limpopo and Zambezi River mouths. The beads are expected to have been produced in the Middle East. Chibuene series are made of low alumina $\left(\mathrm{Al}_{2} \mathrm{O}_{3}<5 \%\right)$ plant ash glass and can be differentiated from the later Zhizo series by a lower magnesium $(\mathrm{MgO}<3 \%)$ and higher potassium content [108]. The second ancient group is called Zhizo, after an earlier Iron Age cultural phase which expanded in most parts of South Africa between the 8th and 10th centuries AD [124]. The beads also arrived in South Africa through the port of Chibuene [108,123] and most of these beads were cut from drawn tubes. Figure 3 shows the colour distribution of beads from different sites (Schoda, K2, Mapungubwe Hill, Leokwe, Magoro Hill and Kolope) [121]. These low alumina soda-lime glass beads are blue, turquoise, yellow and rarely dark green. They were probably produced in the Near/Middle East [107]. 


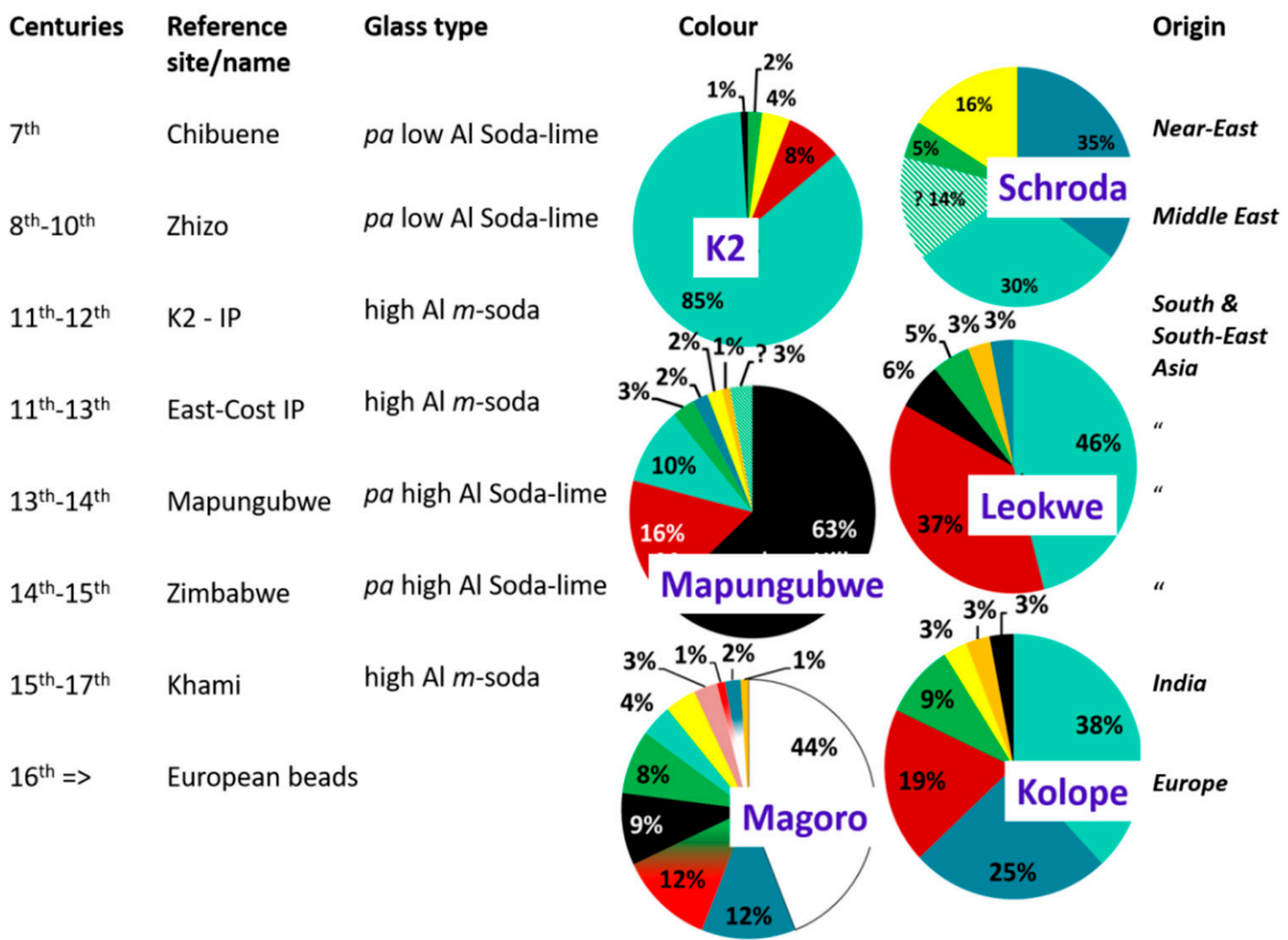

Figure 3. Schematic of the bead series according to Wood's morphological classification indicating the general type of composition for each series [94,121]. The changing colour palette with time is illustrated (turquoise, blue, red, black, light green, green, yellow, orange and white) (see text and Table 1). Bead types are named in relation with the first representative sites where beads have been excavated; $p a$ : plant ash, $m$ : mineral.

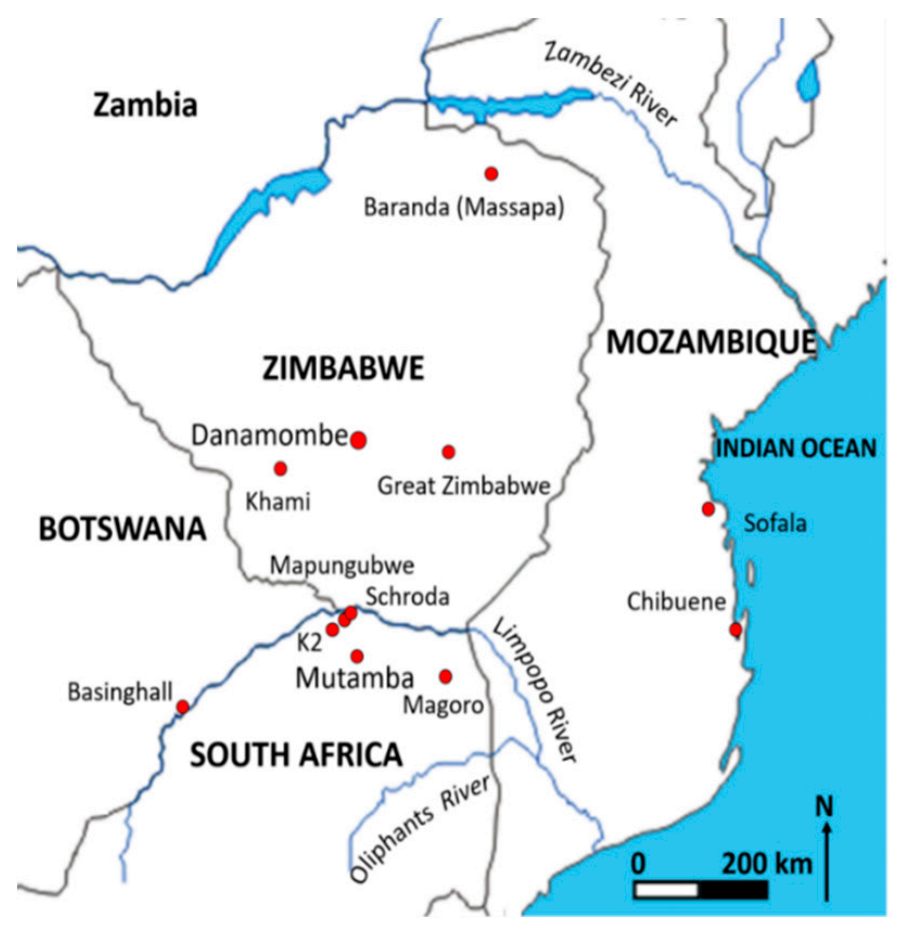

Figure 4. Map showing the location of the archaeological sites referred to in the paper. 
The third group, K2-IP (IP for Indo-Pacific), is associated with the archaeological site of K2 (Figure 4), close to Mapungubwe Hill, in the middle of the Limpopo River valley, close to the modern borders of South Africa, Zimbabwe and Botswana [73]. K2 beads have also been recovered from other regions (e.g., Leokwe) and distant sites in Madagascar and Mozambique with contemporary archaeological context modifications $[79,107,125,126]$. The colour of this high alumina (mineral) soda glass is mainly turquoise and green (Figure 3). Brownish-red and black beads with the same glass composition belong to the late $\mathrm{K} 2$ period and are similar to the beads found on the east coast of Africa (EC-IP series) [122]. The yellow beads also belong to EC-IP series as well but arrived in the region at the same time with the K2 turquoise beads [122]. The beads of the mid-10th to 13th centuries (K2 and EC periods) with high alumina soda composition are grouped in the IP series and are assumed to have been imported from South and Southeast Asia. The variety of colours among the EC-IP beads is greater than for the K2-IP series and consists of green, yellow, black and brownish-red.

The next series is named the Mapungubwe Oblates after their oblate shape and Mapungubwe Hill where they were first excavated. This series has a different composition in comparison to the previous series, notably with higher magnesium content (plant ashes, soda-lime with high alumina). It should be noted that the Leokwe colour palette (Figure 3) is intermediate between that of K2 and Mapungubwe Hill where $\sim 60 \%$ of the beads are black and the others are brownish-red, turquoise, green, blue and yellow. The last series before the arrival of Portuguese merchants is the Zimbabwe series named after Great Zimbabwe [123], with similar composition as the Mapungubwe series.

The most recent non-European series is Khami, named after the site in western Zimbabwe (Figure 4). The composition is different, in the form of high alumina (mineral) soda glass close to the preceding IP series. The colour palette is also different such as the beads from Kolope site (16th century, Figure 3) [121,122]. The bead colours are turquoise, blue and brownish-red as well as rare green, black, yellow and orange. Blue (cobalt) beads of the IP series type were imported for the first time during the Khami period. This period coincides with the arrival of the European traders (first the Portuguese, then the Dutch merchants) but the number of European beads is very low as observed at Baranda and Danamombe sites in Zimbabwe $[83,95]$ as the early European traders also initially sourced their beads in India. It is only in the mid-17th century that a rise in European bead numbers as well as a variety of colours and compositions is documented [94,127]. The colours of the European beads are like those of Magoro Hill (Figure 3), in northern South Africa [94]. It has been demonstrated that many morphological criteria of Wood's classification do not work and may lead to false identifications because European producers copied the shapes and colours of ancient beads, highly prized by the African communities [94].

Figure 5 shows the different types of glass composition based on $\mathrm{Al}, \mathrm{Ca}$ and $\mathrm{Mg}+\mathrm{K}$ oxide content in a ternary composition diagram. This type of diagram discriminates between high alumina and low alumina glasses (high alumina glasses are recognized as characteristic of South Asian and South European productions), potash and soda-lime glasses and the mineral from the plant ash glasses (Mg content). Beads excavated at Magoro Hill, an important site related to the Limpopo River trade and occupied almost continuously from the 7th to the 19th century AD [94], Other samples belong to Mutamba (13th-14th century AD) [82], Maryland and Parma (15th-20th century AD) as later Iron-Age sites in northern South Africa [128] as well as Baranda (16th-17th century AD) in Zimbabwe [95]. Six of the aforementioned series were identified. It is also possible to discriminate six European glass compositions as follows: soda-rich plant ash glasses from northern and southern Europe (15th-18th century AD), potash glass from central Europe (early 18th-mid 19th century AD), mineral-soda glass (recycled), synthetic-soda glass (19th century AD) and mixed alkali glass [128]. The southern European glass, except Venice productions, contains higher alumina (more than $3 \%$ ) in comparison to the northern and central European productions [129]. 


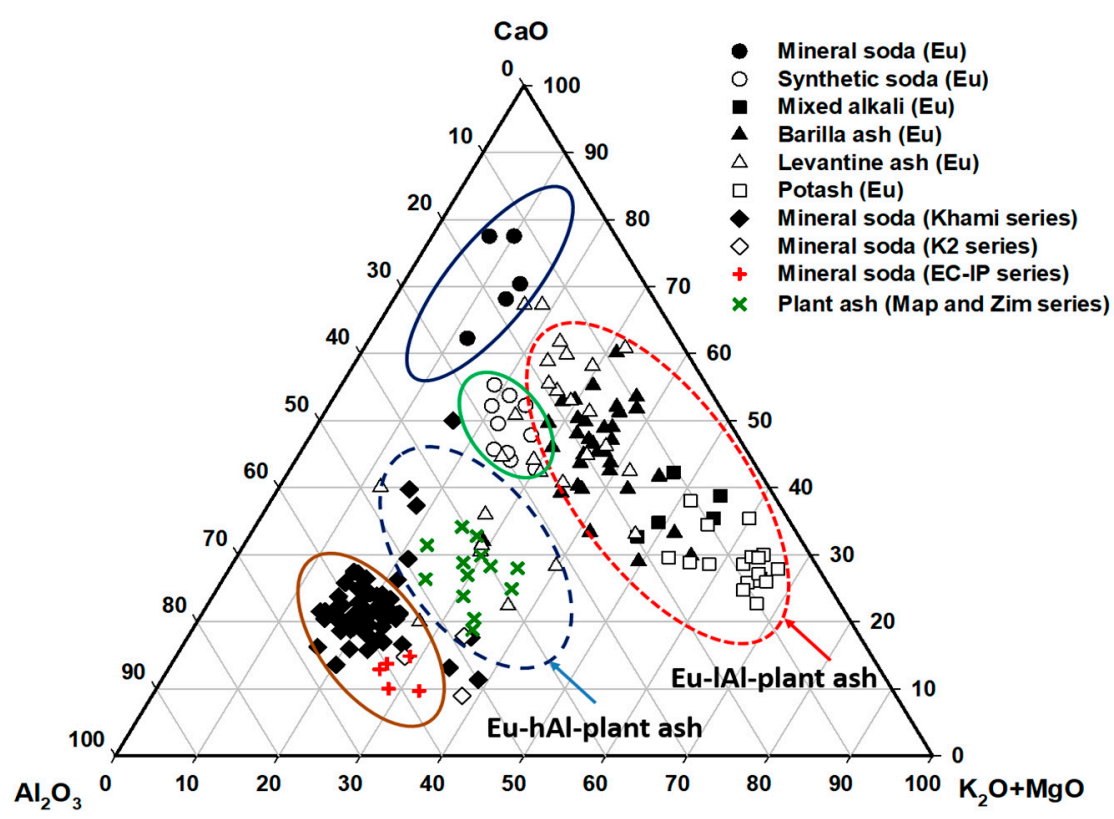

Figure 5. Al-Ca-Mg+K oxides ratio diagram highlighting the different types of glass (h: high; l: low). The symbols used for each series are given. Dashed and solid lines delimit the main soda-lime plant ash and soda glass compositions.

Figure 6 shows the different types of Raman signatures obtained. The Raman classification of the glass network derived from the wavenumber of the summit of the two main Raman peaks (bending and stretching modes of the $\mathrm{SiO}_{4}$ tetrahedron respectively) as the basic unit of silicate glasses is given in Figure 7. The classification method is somewhat different from that obtained by considering elemental composition [129-131], but more efficient to discriminate between soda and soda-lime glasses than the compositional data [132]. Mineral soda glass beads of the IP series and some of the European beads are identified with peak maxima around $450-510 \mathrm{~cm}^{-1}$ and $1100-1060 \mathrm{~cm}^{-1}$ (Figure 6, spectra 1 and 2) [132]. Colorants and secondary phases in glass have an effect on the spectrum shape, as it is observed in spectrum 2. This spectrum belongs to the EC and Khami-IP beads with high iron which was used as colorant in combination with copper to form red, green and blue-green beads [78].

All the Mapungubwe and Zimbabwe as well as some of the Khami and European bead series show a shift in the bending massif towards a higher wavenumber $\left(550-620 \mathrm{~cm}^{-1}\right)$, characteristic of soda-lime glass (Figure 6, spectra 3 and 4) [92]. Spectrum 4 was recorded on the EC and Khami-IP beads with high iron content [78]. Spectra 5 and 6 belong to European beads (Bohemian hexagonal beads) with high potassium (potash-lime) and lead arsenate glass respectively [94]. The maximum of the peak for the Si-O stretching component shifted downward $\left(<1060 \mathrm{~cm}^{-1}\right)$ in lead-based glass with bending maximum around $450-500 \mathrm{~cm}^{-1}$ and forms the cluster beneath the soda group (Figure 7). The same shift is observed for beads with a high calcium content and inhomogeneous chemical structure (reprocessed glass) (Figure 8, spectrum 9). This identification can be made by field archaeologists with a portable instrument on-site. 


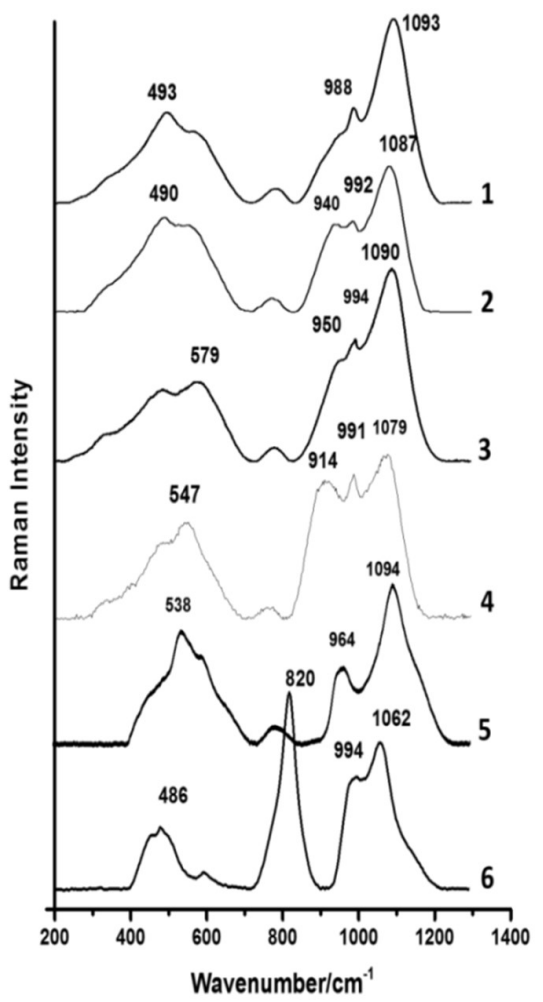

Figure 6. Representative Raman signatures of: soda glass of the IP series (spectrum 1); soda glass with high iron content used as colorant (2); soda-lime glass of the Mapungubwe Oblate, and some of the Khami-IP series and European beads (3); soda-lime glass with high iron content (mostly recorded for green and yellow Khami-IP series) (4); soda-lime glass recorded on European beads with high potassium (5); lead arsenate glass recorded on European beads (6). A baseline has been subtracted according to the procedure described in Colomban [92].

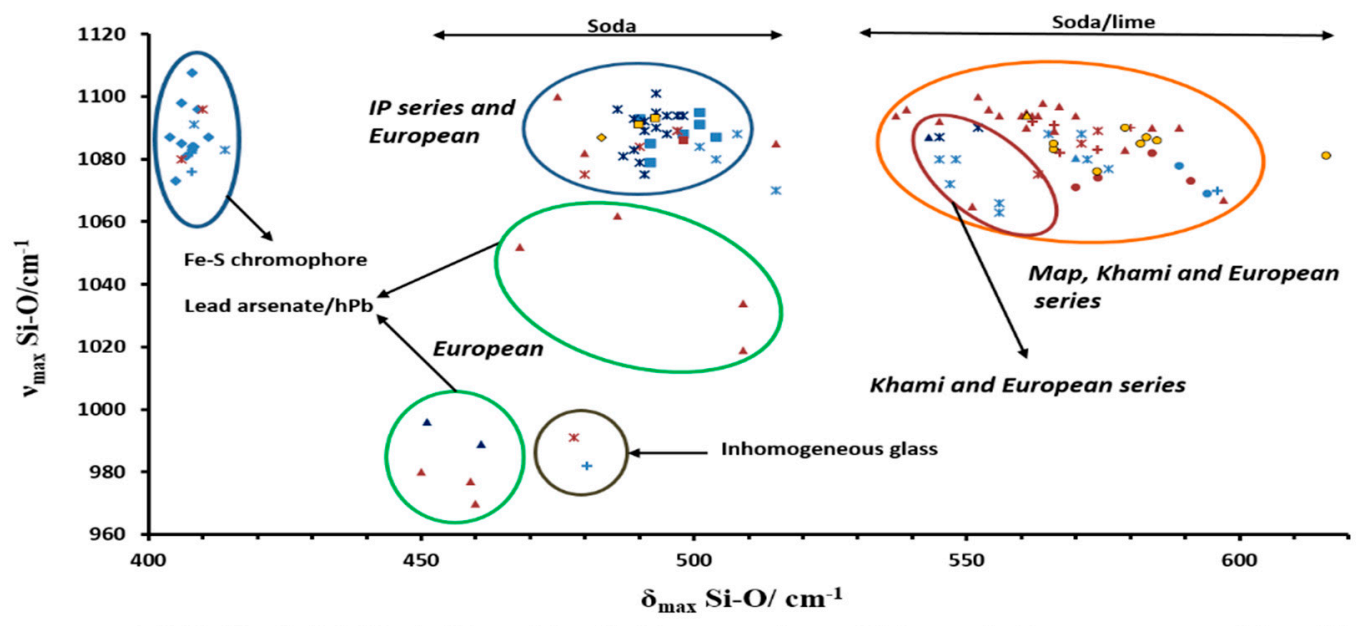

[K2-IP, $\bullet$ EC-IP, * Khami-IP, $\bigcirc$ Mapungubwe Oblate, $\Delta$ European, + unidentified

Figure 7. The plot of $\mathrm{Si}-\mathrm{O}$ bending vs. stretching vibrational modes of glass beads found in South Africa, classifying the different glass series. Basinghall Farm (light blue), Baranda (dark blue), Magoro Hill (brownish-red) and Mutamba (yellow). 

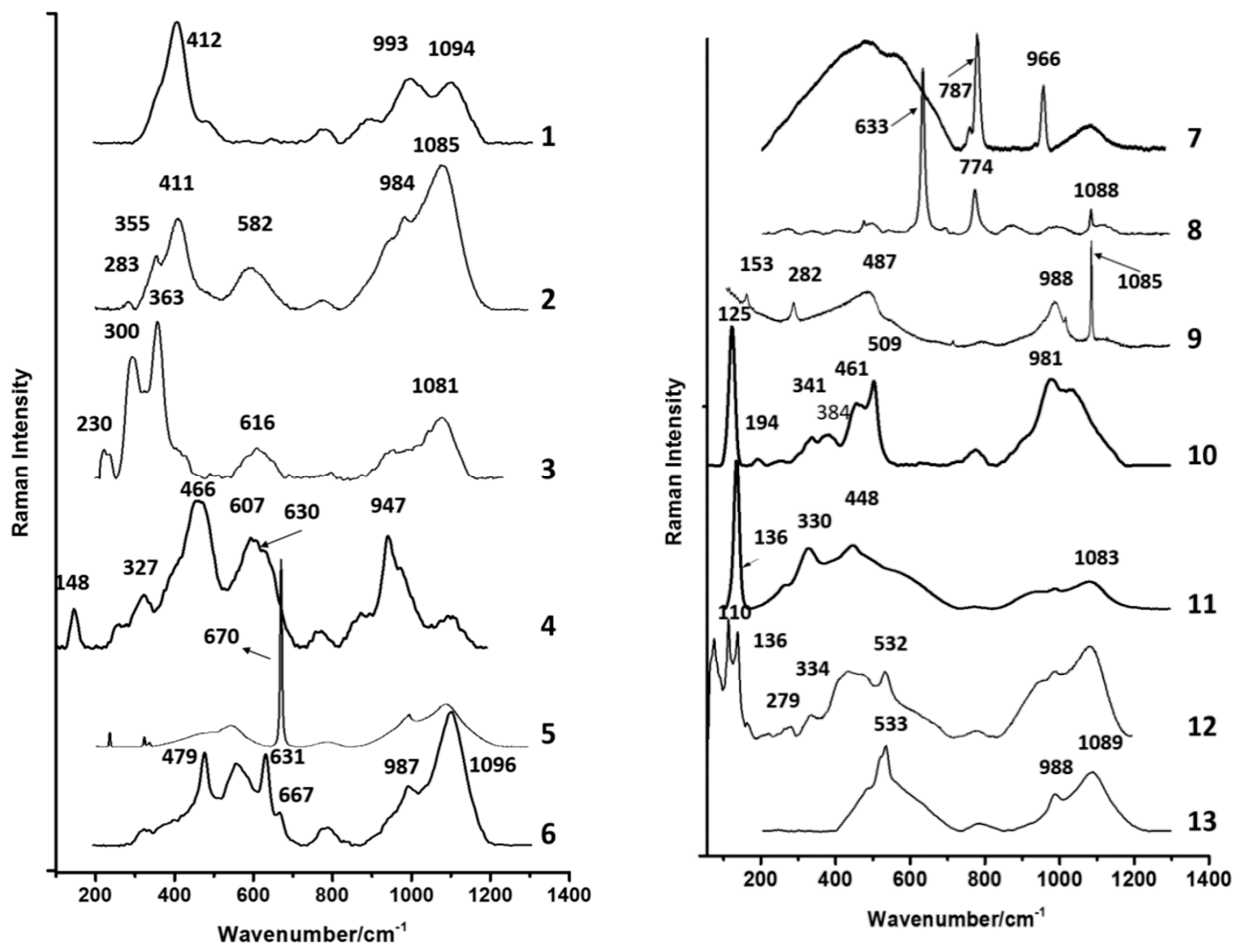

Figure 8. Representative Raman signatures of pigments, opacifiers and secondary phases: Fe-S chromophore in black IP series (spectrum 1); Fe-S chromophore with an extra peak at $355 \mathrm{~cm}^{-1}$ which shows a high concentration of the chromophore (IP series) (2); Fe-S chromophore in black Mapungubwe Oblate (Mutamba) (3); manganese oxide (jacobsite) in a black European bead (Magoro Hill) (4); calcium antimonate $\left(\mathrm{CaSb}_{2} \mathrm{O}_{6}\right)$ used as white pigment in a white European bead (Baranda) (5); calcium antimonates $\left(\mathrm{Ca}_{2} \mathrm{Sb}_{2} \mathrm{O}_{7}\right.$ and $\left.\mathrm{CaSb}_{2} \mathrm{O}_{6}\right)$ in European beads (Magoro Hill) (6); malayite in one cobalt blue bead (Magoro Hill) (7); tin oxide used as opacifier in Mapungubwe Oblate (Mutamba) (8); calcium carbonate impurity in a reprocessed glass bead (Basinghall) (9); $\mathrm{Pb}-\mathrm{Sn}-\mathrm{Sb}$ triple oxide in European beads (Magoro Hill) (10); lead tin yellow (II) detected in Khami-IP and Mapungubwe series (11); a mix of lead tin yellow (II) and lead oxide in orange Mapungubwe Oblate and Khami-IP (12); lazurite pigment in blue Mediterranean beads (Magoro Hill) (13).

\subsection{Matrix and Colouring Agent Composition as Chrono-Technological Markers}

Table 2 lists the different opacifying/colouring agents and secondary phases detected in the beads from this study. As mentioned above, the earliest glasses prepared have a green hue due to the impurities, mainly iron ions. Later, the discovery of the capacity of manganese ions to eliminate the green hue due to $\mathrm{Fe}^{3+}$ ions led to colourless glass. Copper which gives turquoise $\left(\mathrm{Cu}^{2+}\right.$ ions in alkali glass), green $\left(\mathrm{Cu}^{2+}\right.$ ions in lead glass) or red $\left(\mathrm{Cu}^{\circ}\right.$ nanoparticles in mainly lead glass) colours, has been used since the Bronze Age [68].

Calcium antimonates were used in Mesopotamia to opacify glass in very early times. Cassiterite was first used at the end of the Roman period as an opacifier [67] and subsequently by Islamic craftsmen $[133,134]$. Antimony and tin are major impurities of lead oxide as the main flux of many glasses and glazes, therefore their precipitation in lead-based glasses and glazes was not really controlled at the beginning. Bonneau et al. [74] quantitatively established the transition between the use of cassiterite (1590-1699), antimony trioxide (1590-1900) and lead arsenate (1799 until after 1900) as white opacifiers with the study of the beads traded in North America. Consequently, improved 
technologies were repeatedly lost. Cobalt was occasionally used by the Egyptians of the 18th Dynasty ( 1500 BC) to colour glass, and then its use ceased for centuries $[9,12,62]$. Lapis lazuli had been used by the Ptolemaic glassmakers [18], then occasionally by the Romans [19]. However, it was not used for centuries up to its extensive use at the Normandy Court [20] and then during the Mamluks Dynasty [21]. Egyptian blue continued to be used by the Roman glaziers and potters before its disappearance at the end of the Roman Empire [135]. During the same period, Han glass was being coloured with the barium homologue of Egyptian blue [69,136,137].

Green shades remained difficult to prepare for a long time. The only method was the dispersion of $\mathrm{Cu}^{2+}$ ions in lead-based and lead-free glass to obtain jade-green and turquoise. With the limited colouration power of dissolved transition metals in the glass network, an alternative way was mixing yellow and blue colours $[18,21,62]$, e.g., the dispersion of a yellow pigment (lead oxide, Naples yellow pyrochlore or lead-tin homologue, see below) in a glass coloured blue with $\mathrm{Co}^{2+}$ ions or/and lapis lazuli grains to form a green colour [21].

Red colour was also rather difficult to obtain. For instance, copper nanoparticles have a very high power of colouration and their concentration should be limited to obtain a vivid colour. The degree of dispersion and grain size of hematite should also be controlled to obtain vivid red or orange. Highly vivid red to yellow colours have been obtained with the use of $\mathrm{Cd}_{1-y} \mathrm{M}_{\mathrm{y}} \mathrm{Se}_{\mathrm{x}-\mathrm{x}} \mathrm{S}_{\mathrm{x}}$ nanoparticles since the first quarter of the 20th century. However, its use was terminated around 1980 due to the toxicity of $\mathrm{Cd}$ and Se elements [71,138]. As demonstrated in the aforementioned examples and those given in Table 2, more or less similar colours can be attained with a large variety of colouring agents that characterise glass production for a given place and period quite well.

Figure 8 shows typical Raman signatures of the pigments observed on glass beads from the southern African sites of Mapungubwe Hill, K2 [132,139], Basinghall [78], Magoro Hill [94], Mutamba [82] and Baranda [95]. The spectra recorded on black beads show the strong bands (ca. $300-400 \mathrm{~cm}^{-1}$ ) which are characteristic of the $\mathrm{Fe}-\mathrm{S}$ resonance Raman modes of the amber chromophore (spectra 1-3) [112]. It should be noted that the quantity of black beads had increased with the arrival of the Mapungubwe Oblates (Figure 3). Although both series of black beads (IP and Mapungubwe) were coloured with the Fe-S chromophore, a more homogenous spinel pigment with consistent Raman spectrum (spectra $1,2)$ was identified in the earlier series (IP). The Fe-S chromophore in the Mapungubwe series has a complex structure (e.g., spectrum 3), which is a criterion used for discrimination between black beads from the two series with the same shape.

Spectrum 5 shows the characteristic signature of $\mathrm{CaSb}_{2} \mathrm{O}_{6}\left(670 \mathrm{~cm}^{-1}\right)$. Spectra 6 and 8 show $\mathrm{Ca}_{2} \mathrm{Sb}_{2} \mathrm{O}_{7}\left(479-631 \mathrm{~cm}^{-1}\right)$ and $\mathrm{SnO}_{2}\left(633-774 \mathrm{~cm}^{-1}\right)$ doublets of the main opacifiers respectively. Cassiterite as an opacifier is limited to green and turquoise beads of the Mapungubwe Oblates among the pre-European series [132]. The 136, 330 and $448 \mathrm{~cm}^{-1}$ triplets (spectrum 11) are characteristic of lead tin yellow (II) pyrochlore while the additional $110 \mathrm{~cm}^{-1}$ peak (spectrum 12) indicates saturation with lead oxide [139-142]. These yellow pigments are widely used in the yellow, orange and green beads of the Mapungubwe, Khami and European series.

Spectra with a calcite signature with the strongest peak at $1085 \mathrm{~cm}^{-1}$ (Basinghall, spectrum 9) are observed in some of the beads made from reprocessed glass which probably belong to a local production (see below). Undissolved calcite phases may have either remained in the glassy matrix due to the low melting temperature or the short duration of the melting process, according to an elaboration far away from the main glass production centres. Peaks at $285-288 \mathrm{~cm}^{-1}$ assigned to chalcopyrite $\left(\mathrm{CuFeS}_{2}\right)$ are also observed in the black and inhomogeneous green beads of IP and Mapungubwe Hill (spectra 2 and 9) [78].

Specific secondary phases with characteristic (resonance) Raman signatures offer a method to identify specific productions. For instance, chrome-doped malayite, a synthetic sphene which is a phase used as a pink pigment since the 18th century [143], was detected in some of the Indo-Pacific beads (spectrum 7) found at different sites such as Antsiraka Boira, Mayotte (12th-13th century) and Magoro Hill in South Africa (13th-17th century) [79,94]. It should be noted that the huge sensitivity of the 
Raman technique allows detecting minor/trace phases not contributing to the bead colour. The source of these beads is different from the IP series found at K2, Mapungubwe Hill and Mutamba since the phase was not detected in this series. The only bead found in Magoro Hill with malayite is a cobalt blue one with high manganese content suggesting that the colorant is typical of Far Eastern Asia sources (Figure 2, a7).

\subsection{Recycled Glass and/or Heterogeneous Reprocessed Beads}

Figure 9 shows the elemental map of the section of a bead made by recycling ancient glass pieces with very different compositions, namely sodium- and potassium-based respectively [78]. SEM-EDS mapping is very efficient to highlight the heterogeneity but the same information can be obtained by Raman microspectroscopy non-destructively, by collecting the Raman spectrum in different spots where the size of the analysed surface is selected from a few to tens/hundreds of $\mu \mathrm{m}^{2}$. At K2 (1100-1220 AD), the local preparation of large beads (the so-called Garden Rollers) by sintering/melting together small beads in a clay mould is well documented [112-114]. Local productions are also documented in other regions of Africa (Table 4). For instance, Carey [115], Opper and Opper [144] and Simak [116] reported that such beads had been produced at Kiffa in southern Mauritania. Haigh [117] and Francis [5] reported the modern production of "powder-glass" or "bodom" beads in some villages in south central Ghana.

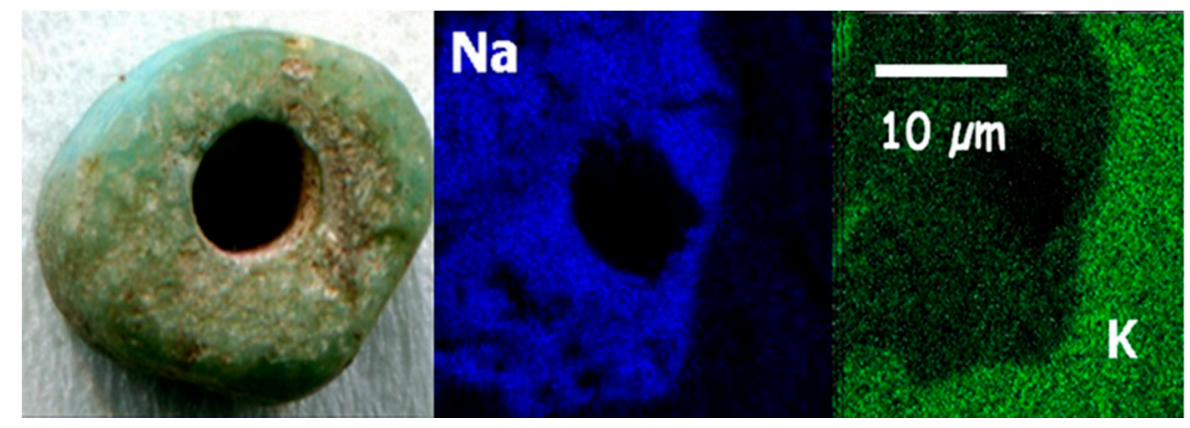

Figure 9. An example of a recycled bead (local production, diameter $\sim 10 \mathrm{~mm}$ ) excavated at Letsibogo site, Basinghall (Bostwana, border with South Africa). SEM-EDS elemental mapping highlights the mixture of soda and potash-glass grains (see details in [78]).

The composition of glass beads from southwest Nigeria (Ile-Ife), determined by LA-ICP-MS, shows unusual high lime-high alumina (HLHA) contents $[111,119,145]$. The simultaneously high contents of lime and alumina in Ile-Ife glass do not match with the compositional databases of the Middle Eastern, Roman, ancient Islamic or Southeast Asian glasses. The concentration of these oxides separates the Ile-Ife glass from other known compositional groups [146,147]. As a result, Lankton et al. [119] concluded that the HLHA glass is evidence of a glassmaking tradition unique to West Africa in or near Ile-Ife.

Recycled glass implies complete melting and homogenisation. This is only possible if the craftsmen have the rare skills and furnaces to melt and produce glass. Recycling can be identified from the elemental composition which is intermediate between those of glasses prepared with specific raw materials. Heterogeneous glass is different from recycled glass. It is a glass made by sintering minute glass beads or crushed glass. A complete melting is not required and processing at lower temperatures with limited facilities is possible. In this case, one of the glasses (or raw materials added) melts and cements the grains. The skills and tools required for this are easier and hence, beads made of sintered glass are potentially local productions. However, a local production is usually only verified if moulds were found such as at K2 (10th-12th century, South Africa) [120] and Igbo Olokun (11th-15th century, Nigeria) (Table 4) [148]. Comparison of compositions or Raman signatures recorded in many spots on the same bead or preferably compositional mapping and microstructural imaging offer new tools to identify a bead made of sintered glass grains. 
Many studies, in particular LA-ICP-MS composition studies postulate that the composition measured on a rather small bead region is representative because glass beads are homogeneous. In fact, this postulate is wrong in many cases because of the heterogeneity due to the use of pigments (the size of the pigment grains can reach a few tens of microns and their distribution is not homogeneous) [67]. On the other hand, Raman signatures of the pure pigment and glassy matrix are currently obtained with the use of different optics: $\times 10$ to $\times 200$ objectives probe a volume variable from ca. $25 \times 25 \times 100$ to $0.5 \times 0.5 \times 3 \mu \mathrm{m}^{3}$ respectively. The different natures of the phases, glassy or crystalline are identified. Recording Raman spectra on different spots can easily detect heterogeneity that can be imaged by mapping. Optical or SEM images and elemental mapping (Figure 9) are necessary to give a global view of the heterogeneity (grain/particulate size, presence of intergranular cement, various compositions of grains) [94]. XRF measurements made with portable instruments, even though their accuracy is lower in comparison to LA-ICP-MS measurements, give a mean value. A multi-disciplinary approach combining Raman, XRF and LA-ICP-MS measurements with optical or electronic microscopy is the best procedure to obtain representative information and to detect beads made of glass mixtures.

\subsection{Discerning between European Replicas and Earlier Ancient Beads}

The number of potential regions where glass was produced as well as trade pathways are less for the beads excavated in earlier sites (before the 15th century) [107]. In later sites, within European archaeological context modifications, a combination of old and modern beads with a variety of sources were found [94]. Some European beads are imitations of the older bead series and consequently, the morphological and visual classification of the beads is inadequate. Information about the composition of the glassy matrix, pigments and opacifiers is essential for discerning between European beads and pre-European bead series. Calcium antimonates (Figure 8, spectra 5-6), arsenates (Figure 6, spectrum 6), $\mathrm{Pb}-\mathrm{Sn}-\mathrm{Sb}$ triple oxides (Figure 8, spectrum 10), manganese oxides (jacobsite) (Figure 8, spectrum 4) in European beads are some of the pigments which were not detected in pre-European series in southern Africa [94,139].

The majority of European glass beads include soda-lime plant ash, mixed alkali, potash and mineral soda and can be discriminated from the earlier trade series (IP, Mapungubwe and Zimbabwe series) with their low percentage of alumina in the composition (Figure 5) [128]. Only a small number of European beads have the same ratios of alumina, lime and potash with glass beads categorized as the Mapungubwe and Zimbabwe series [128]. These European beads with a high alumina content (more than 3\%) were produced in South Europe using sand and Levantine or West Mediterranean plant ashes. They can be discriminated from the earlier series by secondary phases (pigments or opacifiers) in the glassy matrix.

Impurities detected in glass are also very useful parameters in identifying the European beads like the secondary phases. Most European beads contain a lower amount of titanium and iron compared to the pre-European series. Except for some lead arsenate beads, uranium content is very low in most of the European beads (less than $10 \mathrm{ppm}$ ). On the other hand, silver, arsenic and nickel were found as the impurities of the cobalt ore used in some of the European blue beads whereas manganese was found in the Asian products [149-152].

A further complicating factor in bead research in sub-Saharan Africa is that the glass beads, especially "seed" beads (resembling the Mapungubwe Oblates in appearance) have become intrinsic to African culture. Millions of beads are still imported each year to craft cultural objects, traditional clothes and objects for the tourism industry. The small size of seed beads and the fact that they are worn by people all over Africa further promote the contamination of archaeological sites with "modern" beads.

\section{Perspectives}

The use of beads as currency and/or exchange tools has been reported by some authors [153-155]. It is noteworthy that huge changes of colour distribution as a function of long periods of trade, as exampled in Figures 2 and 3, are observed. The availability of some colours could have been 
limited because of the requirement of special raw materials such as cobalt or lapis lazuli. In that case, the origin from special sites of production is likely. The lack of cobalt blue in some of the earlier IP series (mid-10th to the early 13th century) as a function of the trade route change from the Middle East towards South and Southeast Asia is an example [122]. After the demise of the Zhizo series, the $\mathrm{K} 2$ turquoise blue was the prominent colour which easily took the place of cobalt blue due to its availability and/or colour preference of the native consumers.

It took time for new colours (brownish-red and black) to be accepted by the hinterland inhabitants in southern Africa. It was only after ca. 1020 and the late K2 period that a low number of brownish-red and black IP beads appeared in archaeological contexts respectively, while yellow and green IP beads (close to the colours of Zhizo series) reached the market at the same time with K2 turquoise blue [122]. On the other hand, the production of turquoise beads (coloured with $\mathrm{Cu}^{2+}$ ions) is an easy process. Accordingly, the proportion of turquoise beads to other coloured ones is generally significant. One could assume that the values of these "common" beads would be lower. The knowledge of the value and equivalence of the different types of beads as a function of time and place should be very interesting to obtain information on economics, as also obtained by checking the quantity of slags produced in an iron workshop or the purity of gold in golden artefacts and coins. Colour choice is also a cultural parameter that could change with community traditions [102].

Surprisingly, black and brownish-red replaced turquoise blue colour with a significant socioeconomic change in the area and the movement of the capital from K2 to Mapungubwe Hill in 1220. This is in coincidence with the changes in trade patterns, the appearance of a new series of beads (Mapungubwe series) and a new demand for them. The evidence mentioned above suggests that the inhabitants did not easily accept a new colour. Therefore, the change in colour preferences of the inhabitants might be related to the social and economic changes and the colour palette of the new imported beads and the numbers of each colour in the market.

The big interest in portable instruments such as Raman and XRF set-ups is their operability on-site by non-specialists, with a rapid performance in analysing representative items selected by experts. This could help to accede to a statistical view of the artefact categories. Recent studies show the efficiency of the techniques in discriminating glass beads categorized as the K2-IP, East Coast-IP, Mapungubwe, Khami and European series.

The potential of LA-ICP-MS in determining isotopes ( $\mathrm{Pb}, \mathrm{Sn}$, etc.) can be a new tool to identify the production place/raw material as demonstrated in the studies of some potteries and beads with the recent work of Costa et al. [84]. The rapid development of the knowledge on glass production sites in Asia will also contribute to a better knowledge of the bead trade. It is necessary to gather more information about the impurities present in each series by analysing more beads from undisturbed and well-dated archaeological contexts. Furthermore, microstructure should be considered with attention to detect sintered glass and hence potential local production.

Author Contributions: P.C. conceptualised the review and wrote the manuscript, F.K. did the Raman and XRD work and contributed to writing the manuscript, I.P. provided archaeological background and contributed to writing the manuscript, L.C.P. contributed to writing the manuscript.

Funding: This research was funded by National Research Foundation (NRF) of South Africa UID 85178, 81857 and 105866 grant number.

Acknowledgments: Authors kindly acknowledge all colleagues involved in the studies on trade beads in South Africa, Botswana and Zimbabwe.

Conflicts of Interest: The authors declare no conflicts of interest.

\section{References}

1. Poupeau, G.; Le Bourdonnec, F.X.; Carter, T.; Delerue, S.; Shackley, M.S.; Barrat, J.A.; Dubernet, S.; Moretto, P.; Calligaro, T.; Milic, M.; et al. The use of SEM-EDS, PIXE and EDXRF for obsidian provenance studies in the Near East: A case study from Neolithic Çatalhöyük (Central Anatolia). J. Archaeol. Sci. 2010, 37, 2705-2720. [CrossRef] 
2. Tykot, R.H. Chemical fingerprinting and source tracing of obsidian: The Central Mediterranean trade in black gold. Acc. Chem. Res. 2002, 35, 618-627. [CrossRef] [PubMed]

3. Beaujard, P. Un seul système-monde avant le 16e siècle? L'océan Indien au cœur de l'intégration de l'hémisphère afro-eurasien. In Histoire Globale, Mondialisations et Capitalisme; Beaujard, P., Berger, L., Norel, P., Eds.; La Découverte-Recherches: Paris, France, 2009; pp. 82-148.

4. Beaujard, P. Les Mondes de L'océan INDIEN, Vol. 1, De la Formation de l'État au Premier Système Monde Afro-eurasien, Vol. 2. L'océan Indien, au Cour des Globalisations de l'Ancien Monde (7e-15e siècles); Armand Colin: Paris, France, 2012.

5. Francis, P., Jr. Asia's Maritime Bead Trade, 300BC to the Present; University of Hawaii Press: Honolulu, HI, USA, 2002.

6. Bonneau, A.; Moreau, J.F.; Hancock, R.G.V.; Karklins, K. Archaeometrical analysis of glass beads: Potential, limitations, and results. Beads J. Soc. Beads Res. 2014, 26. Available online: http://surface.syr.edu/beads/vol26/ iss1/7 (accessed on 20 April 2019).

7. Hancock, R.G.V.; McKechnie, J.; Aufreiter, S.; Karklins, K.; Kapches, M.; Sempowski, M.; Moreau, J.F.; Kenyon, I. Non-destructive analysis of European cobalt blue glass trade beads. J. Radioanal. Nucl. Chem. 2000, 244, 567-573. [CrossRef]

8. Saitowitz, S.J. Classification of glass trade beads. S. Afr. Mus. Bull. 1988, 18, 41-45.

9. Janssens, K. (Ed.) Modern Methods for Analysing Archaeological and Historical Glass, 1st ed.; J. Wiley \& Sons: Chichester, UK, 2013.

10. Brill, R.H. The Chemical interpretation of the texts. In Glass and Glassmaking in Ancient Mesopotamia; Oppenheim, L., Brill, R.H., Barag, D., von Saldern, A., Eds.; The Corning Museum of Glass: New York, NY, USA, 1970; pp. 105-108.

11. Henderson, J. Ancient Glasses, an Interdisciplinary Exploration; Cambridge University Press: Cambridge, UK, 2013.

12. Shortland, A.J. Lapis Lazuli from the Kiln: Glass and Glassmaking in the Late Bronze Age; Leuven University Press: Leuven, Belgium, 2012.

13. Tite, M.S.; Shortland, A.J. Production Technology of Faience and Related Early Vitreous Materials; Monograph 72; School of Archaeology, University of Oxford: Oxford, UK, 2008.

14. Jackson, C.M. Making colourless glass in Roman Period. Archaeometry 2005, 47, 763-780. [CrossRef]

15. McGray, P. (Ed.) Prehistory and History of Glassmaking Technology; Ceramics and Civilization Series; The American Ceramic Society: Westerville, OH, USA, 1998; Volume VIII.

16. Schuler, F. Ancient glassmaking techniques: The molding process. Archaeology 1959, 12, 47-52.

17. Degryse, P.; Schneider, J. Pliny the Elder and Sr-Nd isotopes: Tracing the provenance of raw materials for Roman glass production. J. Archaeol. Sci. 2008, 35, 1993-2000. [CrossRef]

18. Caggiani, M.C.; Colomban, P.; Mangone, A.; Valloteau, C.; Cambon, P. Mobile Raman spectroscopy analysis of ancient enamelled glass masterpieces. Anal. Methods 2013, 5, 4345-4354. [CrossRef]

19. Greiff, S.; Schuster, J. Technological study of enamelling on Roman glass: The nature of opacyfing, decolourising and fining agents used with the glass beakers from Lübsow (Lubieszewo, Poland). J. Cult. Herit. 2008, 9, e27-e32. [CrossRef]

20. Caggiani, M.C.; Valloteau, C.; Colomban, P. Inside the glassmaker technology: Search of Raman criteria to discriminate between Emile Gallé and Philippe-Joseph Brocard Enamels and Pigment Signatures. J. Raman Spectrosc. 2014, 45, 456-464. [CrossRef]

21. Colomban, P.; Tournié, A.; Caggiani, M.C.; Paris, C. Pigments and enamelling/gilding technology of Mamluk mosque lamps and bottle. J. Raman Spectrosc. 2012, 43, 1975-1984. [CrossRef]

22. Henderson, J. Tradition and experiment in first millennium A.D. glass production. The emergence of early Islamic glass technology in late antiquity. Acc. Chem. Res. 2002, 35, 594-602. [CrossRef] [PubMed]

23. Davidson, S.; Newton, R.G. Conservation and Restoration of Glass; Routledge: Abingdon, UK, 2008.

24. Ricciardi, P.; Colomban, P.; Tournié, A.; Milande, V. Non-destructive on-site identification of ancient glasses: Genuine artefacts, embellished pieces or forgeries? J. Raman Spectrosc. 2009, 40, 604-617. [CrossRef]

25. Cothren, M.W. Picturing the Celestial City: The Medieval Stained Glass of Beauvais Cathedral; Princeton University Press: Princeton, NJ, USA, 2006.

26. Cummings, K. A History of Glass Forming; University of Pennsylvania Press: Philadelphia, PA, USA, 2002. 
27. Sayre, E.V.; Smith, R.W. Compositional categories of ancient glass. Science 1961, 133, 1824-1826. [CrossRef] [PubMed]

28. Galuska, L.; Machacek, J.; Pieta, K.; Sedlackova, H. The glass of great Moravia: Vessel and Window glass, and small Objects. J. Glass Stud. 2012, 54, 61-65.

29. Armitage, E.L. Stained Glass: History, Technology and Practice; Leonard Hill: London, UK, 1959.

30. Glover, I.C.; Henderson, J. Early glass in South and South-East Asia, China and South-East Asia. In Art Commercial Interaction; Percival David Foundation of Chinese Art: London, UK, 1995; pp. 141-169.

31. Henderson, J.; Chenery, S.; Kröger, J.; Faber, E.W. Glass provenance along the Silk Road: The use of trace element analysis. In Recent Advances in the Scientific Research on Ancient Glass and Glaze; Gan, F., Li, Q., Henderson, J., Eds.; Series on Archaeology and History of Science in China; World Scientific: Singapore, 2016; Volume 2, pp. 17-42.

32. Tamura, T.; Oga, K. Archaeometrical investigation of natron glass excavated in Japan. Microchem. J. 2016, 126, 7-17. [CrossRef]

33. Zhang, Z.; Ma, Q. Faience beads of the western Zhou Dynasty excavated in Gansu province, China: A technical study. In Ancient Glass Research along the Silk Road; Gan, F.X., Brill, R., Tian, S., Eds.; World Scientific: Singapore, 2009; pp. 275-289.

34. Dussubieux, L.; Kusimba, C.M.; Gogte, V.; Kusimba, S.B.; Gratuze, B.; Oka, R. The trading of ancient glass beads: New analytical data from South Asian and East African soda-alumina glass beads. Archaeometry 2008, 50, 797-821. [CrossRef]

35. Gan, F.; Li, Q.; Henderson, J. (Eds.) Recent Advances in the Scientific Research on Ancient Glass and Glaze; Series on Archaeology and History of Science in China; World Scientific: Singapore, 2016; Volume 2.

36. Colomban, P.; Khoi, D.N.; Liem, N.Q.; Roche, C.; Sagon, G. Sa Huynh and Cham potteries: Microstructure and likely processing. J. Cult. Herit. 2004, 5, 149-155. [CrossRef]

37. Saminpanya, S.; Bavornyospiwat, N.; Homklin, S.; Danyutthapolchai, S.; Bupparenoo, P. Physical and chemical properties of the ancient glass beads from the highland log-coffin culture and the lowland areas, Thailand: Considerations on their colors and technology. J. Archaeol. Sci. Rep. 2016, 8, 366-380. [CrossRef]

38. Bouzougar, A.; Barton, N.; Vanhaeren, M.; D'Errico, F. 82,000-year-old shell beads from North Africa and implications for the origins of modern Human behaviour. Proc. Natl. Acad. Sci. USA 2007, 104, 9964-9969. [CrossRef] [PubMed]

39. Holden, C. Oldest beads suggest early symbolic behaviour. Science 2004, 304, 369. [CrossRef] [PubMed]

40. Abraham, S.A. Glass beads and glass production in early south India: Contextualizing Indo-Pacific bead manufacture. Archaeol. Res. Asia 2016, 6, 4-15. [CrossRef]

41. Carter, A.K.; Abraham, S.A.; Kelly, G.O. Updating Asia's Maritime Bead Trade: An Introduction. Archaeol. Res. Asia 2016, 6, 1-3. [CrossRef]

42. Kelly, G.O. Heterodoxy, orthodoxy and communities of practice: Stone bead and ornament production in Early Historic South India (c. 400 BCE-400 CE). Archaeol. Res. Asia 2016, 6, 30-50. [CrossRef]

43. Wood, M. Glass beads from pre-European contact sub-Saharan Africa: Peter Francis's work revisited and updated. Archaeol. Res. Asia 2016, 6, 65-80. [CrossRef]

44. Wood, M.; Panighello, S.; Orsega, E.F.; Robertshaw, P.; van Elteren, J.T.; Crowther, A.; Horton, M.; Boivin, N. Zanzibar and Indian Ocean trade in the first millennium Ce: The glass bead evidence. Archaeol. Anthropol. Sci. 2017, 9, 879-901. [CrossRef]

45. Van der Sleen, W.G.N. A Handbook on Beads; Liberty Cap Books: York, PA, USA, 1973.

46. Freestone, I.C. The provenance of ancient glass through compositional analysis. Mater. Res. Soc. Symp. Proc. 2005, 852, 1-14. [CrossRef]

47. Colomban, P.; Tournié, A. On-site Raman Identification and Dating of Ancient/Modern Stained Glasses at the Sainte-Chapelle, Paris. J. Cult. Herit. 2007, 8, 242-256. [CrossRef]

48. Degryse, P. Glass Making in the Graeco-Roman World; Leuven University Press: Leuven, Belgium, 2014.

49. Foy, D.; Nenna, M.D. Echanges et commerce du verre dans le monde antique. In Monographies Instrumentum 24, Actes du Colloque de L'Association Française pour l'Archéologie du Verre (AFAV), Aix-en-Provence-Marseille, 7-9 juin 2001; CNRS-mmsh-Université: Aix-Marseille, France, 2003; ISBN 2-907303-72-4. 
50. Picon, M.; Vichy, M. D'Orient en Occident: l'origine du verre à l'époque romaine et durant le haut Moyen Age. In Échanges et Commerce du verre dans le Monde Antique Monographies Instrumentum 24, Actes du Colloque de L'Association Française pour l'Archéologie du Verre (AFAV), Aix-en-Provence-Marseille, 7-9 juin 2001; CNRS-mmsh-Université: Aix-Marseille, France, 2003; pp. 17-31. ISBN 2-907303-72-4.

51. Valooto, M.; Verità, M. Glasses from Pompei, Herculaneum, and the sand of the rivers Belus and Volturno. Studi della Soprintend. Archeol. di Pompei 2002, 6, 63-73.

52. Freestone, I. Pliny on Roman glassmaking. In Archaeology, History and Science: Integrating Approaches to Ancient Materials; Martinon-Torres, M., Rehren, T., Eds.; Left Coast Press: Walnut Creek, CA, USA, 2008; pp. 77-100.

53. Verità, M.; Zecchin, S. Thousand years of Venetian glass: The evolution of chemical composition from the origins to the 18th century. In Annales du 17e Congrès de l'Association Internationale pour l'Histoire Du Verre (AIHV); Janssens, K., Degryse, P., Cosyns, P., Caen, J., Van't dack, L., Eds.; Antwerp, 4th to 8th September 2006; Aspeditions: Antwerp, Belgium, 2009; pp. 602-613.

54. De Raedt, I.; Janssens, K.; Veekman, J.; Vincze, J.; Vekemans, B.; Jeffries, T.E. Trace analysis for distinguishing between Venetian and façon-de-Venise glass vessels of the 16th and 17th century. J. Anal. At. Spectrosc. 2001, 16, 1012-1017. [CrossRef]

55. Šmit, Ž.; Janssens, K.; Schalm, O.; Kos, M. Spread of Façon-de-Venise Glassmaking through Central and Western Europe. Nucl. Instrum. Methods Phys. Res. B 2004, 213, 717-722. [CrossRef]

56. Francis, P., Jr. Glass Beads in Asia: Part I. Introduction, Asian Perspectives; University of Hawai'i Press: Honolulu, HI, USA, 1989; Volume 28, pp. 1-21.

57. Dungworth, D. Three and a half centuries of bottle manufacture. Ind. Archaeol. Rev. 2012, 34, 37-50. [CrossRef]

58. Bertran, H. Nouveau Manuel Complet de la Peinture sur Verre, sur Porcelaine et sur Email; Encyclopédie-Roret-Ed; Mulo, L.: Paris, France, 1913.

59. Brisac, C. A Thousand Years of Stained Glass; Book Sales: Macdonald, CA, USA, 1986.

60. Cappa, G. Le génie verrier de l'Europe. Témoignages de l'Historicisme à la Modernité (1840-1998), 2nd ed.; Mardaga: Liège, Belgium, 1991.

61. Bontemps, G. Guide du Verrier - Traité historique et pratique de la fabrication des verres, cristaux, vitraux; Librairie du Dictionnaire des Arts Manufacturés: Paris, France, 1868.

62. Colomban, P. The destructive/non-destructive identification of enamels, pottery, glass artifacts and associated pigments-A brief overview. Arts 2013, 2, 77-110. [CrossRef]

63. Eppler, R.A.; Eppler, D.F. Glazes and Glass Coatings; The American Ceramic Society: Westerville, OH, USA, 2000.

64. Nassau, K. The Physics and Chemistry of Color, 2nd ed.; Wiley-VCH: New York, NY, USA, 2001.

65. Tilley, R. Colour and the Optical Properties of Materials; Wiley and Sons: Chichester, UK, 2000.

66. Colomban, P.; Sagon, G.; Faurel, X. Differentiation of antique ceramics from the Raman spectra of their coloured glazes and paintings. J. Raman Spectrosc. 2001, 32, 351-360. [CrossRef]

67. Neri, E.; Morvan, C.; Colomban, P.; Guerra, M.F.; Prigent, V. Late Roman and Byzantine Mosaic opaque "Glass-ceramics" Tesserae (5th-9th century). Ceram. Int. 2016, 42, 18859-18869. [CrossRef]

68. Colomban, P. The use of metal nanoparticles to produce yellow, red and iridescent colour, from Bronze Age to present times in lustre pottery and glass: Solid State Chemistry, Spectroscopy and Nanostructure. J. Nano Res. 2009, 8, 109-132. [CrossRef]

69. Berke, H.; Wiedemann, H.G. The chemistry and fabrication of anthropogenic pigments Chinese blue and purple in ancient China. East Asian Sci. Technol. Med. 2000, 17, 94-120.

70. Colomban, P.; Tournié, A.; Ricciardi, P. Raman spectroscopy of copper nanoparticle-containing glass matrices: Ancient red stained-glass windows. J. Raman Spectrosc. 2009, 40, 1949-1955. [CrossRef]

71. Fornacelli, C.; Colomban, P.; Turbanti Memmi, I. Toward a Raman/FORS discrimination between Art Nouveau and contemporary stained glasses from $\mathrm{CdS}_{\mathrm{x}} \mathrm{Se}_{1-\mathrm{x}}$ nanoparticles signatures. J. Raman Spectrosc. 2015, 46, 1129-1139. [CrossRef]

72. Pollard, A.M.; Heron, C. Archaeological Chemistry; Royal Society of Chemistry: Cambridge, UK, 1996.

73. Fouché, L. Mapungubwe: Ancient Bantu Civilization on the Limpopo. Reports on excavations at Mapungubwe; Cambridge University Press: Cambridge, UK, 1937. 
74. Bonneau, A.; Moreau, J.F.; Auger, R.; Hancock, R.G.V.; Émard, B. Analyses physico-chimiques des perles de traite en verre de facture européenne: Quelles instrumentations pour quels résultats ? Archéologiques 2014, 26, 109-132.

75. Colomban, P. Analyse non destructive des objets d'art par méthodes spectroscopiques portables. Tech. de l'Ingénieur 2012, 217, 1-12.

76. Colomban, P. The on-site/remote Raman analysis with portable instruments-A review of drawbacks and success in Cultural Heritage studies and other associated fields. J. Raman Spectrosc. 2012, 43, 1529-1535. [CrossRef]

77. Bellina, B. Maritime Silk Roads' Ornament Industries: Socio-political Practices and Cultural Transfers in the South China Sea. Camb. Archaeol. J. 2014, 24, 345-377. [CrossRef]

78. Koleini, F.; Prinsloo, L.C.; Biemond, W.M.; Colomban, P.; Ngo, A.; Boeyens, J.; van der Ryst, M. Towards refining the classification of glass trade beads imported into southern Africa from the 8th to the 16th century AD. J. Cult. Herit. 2016, 19, 435-444. [CrossRef]

79. Fischbach, N.; Ngo, A.T.; Colomban, P.; Pauly, M. Beads excavated from Antsiraka Boira necropolis (Mayotte Island, 12th-13th century); Colouring agents and glass matrix composition comparison with contemporary Southern Africa sites. Revue d'Archéomètrie-Archéosciences 2016, 40, 83-102. [CrossRef]

80. Vicenzi, E.P.; Eggins, S.; Logan, A.; Wysoczanski, R. Microbeam characterization of Corning archaeological references glasses. New additions to the Smithsonian microbeam standard collection. J. Res. Natl. Inst. Stand. Technol. 2002, 107, 719-727. [CrossRef]

81. Simsek, G.; Colomban, P.; Casadio, F.; Bellot-Gurlet, L.; Faber, K.; Zelleke, G.; Milande, V.; Tilliard, L. On-site identification of early Böttger red stonewares using portable XRF/Raman instruments: 2 glaze and gilding analysis. J. Am. Ceram. Soc. 2015, 98, 3006-3013. [CrossRef]

82. Koleini, F.; Colomban, P.; Antonites, A.; Pikirayi, I. Raman and XRF classification of Asian and European glass beads recovered at Mutamba, a southern African Middle Iron Age site. J. Archaeol. Sci. Rep. 2017, 13, 333-340. [CrossRef]

83. Koleini, F.; Machiridza, L.H.; Pikirayi, I.; Colomban, P. The chronology of Insiza cluster Khami-phase sites in south-western Zimbabwe: Compositional insights from pXRF and Raman analysis of excavated exotic glass finds. Archaeometry 2019, 61, 874-890. [CrossRef]

84. Costa, M.; Barrulas, P.; Dias, L.; da Conceição Lopes, M.; Barreira, J.; Clist, B.; Karklins, K.; da Piedade de Jesus, M.; da Silva Domingos, S.; Vandenabeele, P.; et al. Multi-analytical approach to the study of the European glass beads found in the tombs of Kulumbimbi (Mbanza Kongo, Angola). Microchem. J. 2019, 149, 103390. [CrossRef]

85. Dussubieux, L.; Gratuze, B.; Blet-Lemarquand, M. Mineral soda alumina glass: Occurrence and meaning. J. Archaeol. Sci. 2010, 37, 1646-1655. [CrossRef]

86. Yuan, H.L.; Gao, S.; Liu, X.M. Accurate U-Pb age and trace element determinations of zircon by laser ablation-inductively coupled plasma-mass spectrometry. Geostand. Geoanal. Res. 2004, 28, 353-370. [CrossRef]

87. Degryse, P.; Henderson, J.; Hodgins, G. Isotopes in Vitreous Materials; Leuven University Press: Leuven, Belgium, 2009.

88. Koch, J.; Günther, D. Review of the State-of-the-Art of Laser Ablation Inductively Coupled Plasmarometry. Appl. Spectrosc. 2011, 65, 155A-162A. [CrossRef] [PubMed]

89. Fotakis, C.; Anglos, D.; Zafiropulos, V.; Georgiou, S.; Tornar, V. Lasers in the Preservation of Cultural Heritage: Principles and Applications; CRC Press: Boca Raton, FL, USA, 2006.

90. Miziolek, A.W.; Palleschi, V.; Schechte, I. Laser Induced Breakdown Spectroscopy; Cambridge University Press: Cambridge, UK, 2006.

91. Gaudiuso, R.; Dell'Aglio, M.; De Pascale, O.; Senesi, G.S.; De Giacomo, A. Laser Induced Breakdown Spectroscopy for elemental analysis in environmental, cultural heritage and space applications: A review of methods and results. Sensors 2010, 10, 7434-7468. [CrossRef] [PubMed]

92. Colomban, P. Polymerisation degree and Raman identification of ancient glasses used for jewellery, ceramics enamels and mosaics. J. Non-Cryst. Solids 2003, 323, 180-187. [CrossRef]

93. Bead Researcher Society. (Compiled by K. Karklins). Available online: https://beadresearch.org/wp-content/ uploads/2016/08/Africa.pdf (accessed on 7 November 2016). 
94. Koleini, F.; Prinsloo, L.C.; Biemond, W.; Colomban, P.; Ngo, A.T.; Boeyens, J.; Van der Ryst, M.M.; van Brakel, K. Glass trade on Magoro Hill, an archaeological site in southern Africa: Glass types and pigments. Herit. Sci. 2016, 4, 1-20.

95. Koleini, F.; Pikirayi, I.; Colomban, P. Revisiting Baranda: A multi-analytical approach in classifying sixteenth/seventeenth-century glass beads from northern Zimbabwe. Antiquity 2017, 91, 751-764. [CrossRef]

96. Beck, H.C. The beads of Mapungubwe District. In Mapungubwe I; Fouché, L., Ed.; Cambridge University Press: Cambridge, UK, 1937; pp. 104-113.

97. Malleret, L. Classification et nomenclature des «perles » archéologiques en fonction de la symétrie minérale. Bull. de l'Ecole française d'Extrême Orient 1949, 51, 117-124. [CrossRef]

98. Van Riet Lowe, C. The Glass Beads of Mapungubwe; Archaeological Series 9; Archaeological Survey: Pretoria, South Africa, 1955.

99. Kidd, K.E.; Kidd, M.A. A classification system for glass beads for the use of field archaeologists. In Proceedings of the 1982 Glass Trade Bead Conference; Hayes, C.F., III, Ed.; Rochester Research Note 16; Rochester Museum and Science Center: New York, NY, USA, 1983; pp. 219-257.

100. Karklins, K. Glass Beads. Studies in Archaeology, Architecture and History; Parks Canada: Ottawa, ON, Canada, 1985.

101. Davidson, C.C.; Clark, J.D. Trade wind beads: An interim report of chemical studies. Azania 1974, 9, 75-86. [CrossRef]

102. Buratti, M. Le symbolisme des couleurs dans les productions perlées du Cameroun. In Les Couleurs dans les Arts D'afrique. De la Préhistoire à nos Jours; Gutierrez, M., Buratti, M., Valentin, M., Ballinger, M., Eds.; Editions des Archives Contemporaines: Paris, France, 2016; pp. 67-82.

103. DAACS. Cataloging Manual Beads. Available online: http://www.daacs.org/wp-content/uploads/2016/10/ DAACSBeadManual.pdf (accessed on 20 May 2019).

104. Decorse, C.R. Beads as chronological indicators in West African archaeology: A re-examination. BEADS J. Soc. Beads Res. 1989, 1, 41-53.

105. Saitowitz, S.J.; Reid, D.L.; van der Merwe, N.J. Bead trade from Islamic Egypt to South Africa c. AD 900-1250. S. Afr. J. Sci. 1996, 92, 101-104.

106. Saitowitz, S.J.; Sampson, C.G. Glass trade beads from rock shelters in the upper Karoo. S. Afr. Archaeol. Bull. 1992, 47, 94-103. [CrossRef]

107. Robertshaw, P.; Wood, M.; Melchiorre, E.; Popelka-Filcoff, R.S.; Glascock, M.D. Southern African glass beads: Chemistry, glass sources and patterns of trade. J. Archaeol. Sci. 2010, 37, 1898-1912. [CrossRef]

108. Wood, M.; Dussubieux, L.; Robertshaw, P. Glass finds from Chibuene, a 6th to 17th century AD port in southern Mozambique. S. Afr. Archaeol. Bull. 2012, 67, 59-74.

109. Rousaki, A.; Coccato, A.; Verhaeghe, C.; Clist, B.O.; Bostoen, K.; Vandenabeele, P.; Moens, L. Combined spectroscopic analysis of beads from the tombs of Kindoki, Lower Congo Province (Democratic Republic of the Congo). Appl. Spectrosc. 2016, 70, 76-93. [CrossRef]

110. Coccato, A.; Costa, M.; Rousaki, A.; Clist, B.O.; Karklins, K.; Bostoen, K.; Manhita, A.; Cardoso, A.; Dias, C.B.; Candeias, A.; et al. Micro-Raman spectroscopy and complementary techniques (hXRF, VP-SEM-EDS, $\mu$-FTIR and Py-GC/MS) applied to the study of beads from the Kongo Kingdom (Democratic Republic of the Congo). J. Raman Spectrosc. 2017, 48, 1458-1478. [CrossRef]

111. Babalola, A.B. Ancient history of technology in West Africa: The Indigenous. Glass/Glass Bead Industry and the Society in Early Ile-Ife, Southwest Nigeria. J. Black Stud. 2017, 48, 501-527. [CrossRef]

112. Prinsloo, L.C.; Colomban, P. A Raman spectroscopic study of the Mapungubwe oblates: Glass trade beads excavated at an Iron Age archaeological site in South Africa. J. Raman Spectrosc. 2008, 39, 79-90. [CrossRef]

113. Davison, C.C. Chemical resemblance of garden roller and M1 glass beads. Afr. Stud. 1973, 32, $247-257$. [CrossRef]

114. Gardner, G.A. Mapungubwe II; J.L. van Schaik: Pretoria, South Africa, 1963.

115. Carey, M. Powder-glass beads in Africa. In Ornaments from the Past: Beads Studies after Beck; Glover, I., Hughes-Brock, H., Henderson, J., Eds.; The Bead Study Trust: London, UK, 2003; pp. 108-114.

116. Simak, E. Traditional Mauritanian Powder-glass Kiffa beads. ORNAMENT 2006, 29, 50-54.

117. Haigh, J. Present-day bead-making in Ghana. In Ornaments from the Past: Bead Studies after Beck; Glover, I., Hughes-Brock, H., Henderson, J., Eds.; The bead Study Trust: Cambridge, UK, 2003; pp. 115-117. 
118. Euba, O. Of blue beads and red; the role of Ife in the West African trade in Kori beads. J. Hist. Soc. Niger. 1982, 11, 109-127.

119. Lankton, J.W.; Ige, O.A.; Rehren, T. Early primary glass production in Southern Nigeria. J. Afr. Archaeol. 2006, 4, 111-138. [CrossRef]

120. Wood, M. Glass beads and Pre-European trade in the Shashe-Limpopo-region. In Master of Arts Dissertation; University of the Witwatersrand: Johannesburg, South Africa, 2005.

121. Wood, M. A glass bead sequence for Southern Africa from the 8th to the 16th century AD. J. Afr. Archaeol. 2011, 9, 67-84. [CrossRef]

122. Wood, M. Interconnections; Glass Beads and Trade in Southern and Eastern Africa and the Indian Ocean-7th to 16th Centuries AD. Ph.D. Thesis, Uppsala University, Uppsala, Sweden, 2012.

123. Wilmsen, E.; Dussubieux, L.; Huffmann, T.; Wood, M. Chemical analyses of glass beads from two Early Iron Age sites in Zimbabwe: Zhizo Hill and Makuru. Aziana Archaeol. Res. Afr. 2018, 53, 369-382. [CrossRef]

124. Huffman, T. Handbook to the Iron Age; University of KwaZulu-Natal Press: Scotville, VT, USA, 2007.

125. Robertshaw, P.; Rasoarifetra, B.; Wood, M.; Melchiorre, E.; Popelka-Filcoff, R.S.; Glascock, M.D. Chemical analysis of glass beads from Madagascar. J. Afr. Archaeol. 2006, 4, 91-109. [CrossRef]

126. Simsek, G.; Colomban, P. New investigation on glass beads from the necropolis of Vohemar, Northern Madagascar. 2019; Unpublished work.

127. Robertshaw, P.; Wood, M.; Haour, A. Chemical analysis, chronology, and context of a European glass bead assemblage from Garumele, Niger. J. Archaeol. Sci. 2014, 41, 591-604. [CrossRef]

128. Koleini, F.; Colomban, P.; Pikirayi, I. Post-15th century European glass beads in southern Africa: Identification, composition and classification using pXRF and Raman spectroscopy. 2019; Submitted for publication.

129. Cagno, S.; Brondi Badano, M.; Mathis, F.; Strivay, D.; Janssen, K. Study of medieval glass from Savona (Italy) and their relation with the glass produced in Altare. J. Archaeol. Sci. 2012, 39, 2191-2197. [CrossRef]

130. Dussubieux, L.; Karklins, K. Glass bead production in Europe during the 17th century/Elemental analysis of glass materials found in London and Amsterdam. J. Archaeol. Sci. Rep. 2016, 5, 574-579. [CrossRef]

131. Robertshaw, P.; Magnavita, S.; Wood, M.; Melchiorre, E.; Popelka-Filcoff, R.; Glascock, M.D. Glass beads from Kissi (Burkina Faso): Chemical analysis and archaeological interpretation. In Crossroads: Cultural and Technological Developments in First Millennium BC/AD West Africa; Magnavita, S., Koté, L., Breunig, P., Idé, O.A., Eds.; Journal of African Archaeology Monograph Series 2; Africa Magna Verlag: Frankfurt, Germany, 2009; pp. 105-118.

132. Prinsloo, L.C.; Tournié, A.; Colomban, P. A Raman spectroscopic study of glass trade beads excavated at Mapungubwe hill and K2, two archaeological sites in southern Africa, raises questions about the last occupation date of the hill. J. Archaeol. Sci. 2011, 38, 3264-3277. [CrossRef]

133. Colomban, P.; Truong, C. Non-destructive Raman study of the glazing technique in lustre potteries and faience (9-14th centuries): Silver ions, nanoclusters, microstructure and processing. J. Raman Spectrosc. 2004, 35, 195-207. [CrossRef]

134. Tite, M.; Pradell, T.; Shortland, A. Discovery, production and use of tin-based opacifiers in glasses, enamels and glazes from the late iron age onwards: A reassessment. Archaeometry 2008, 50, 67-84. [CrossRef]

135. Pages-Camagna, S.; Colinart, S.; Coupry, C. Fabrication process of archaeological Egyptian blue and green pigments enlightened by Raman microscopy and scanning electron microscopy. J. Raman Spectrosc. 1999, 30, 313-317. [CrossRef]

136. Cheng, X.; Yin, X.; Ma, Y.; Lei, Y. Three fabricated pigments (Han purple, indigo and emerald green) in ancient Chinese artifacts studied by Raman microscopy, energy-dispersive $\mathrm{X}$-ray spectrometry and polarized light microscopy. J. Raman Spectrosc. 2007, 38, 1274-1280. [CrossRef]

137. Lei, Y.; Xia, Y. Study on production techniques and provenance of faience beads excavated in China. J. Archaeol. Sci. 2015, 53, 32-42. [CrossRef]

138. Prinsloo, L.C.; Boeyens, J.C.A.; Van der Ryst, M.M.; Webb, G. Raman signatures of the modern pigment $(\mathrm{Zn}, \mathrm{Cd}) \mathrm{S}_{1-\chi} \mathrm{Se}_{\chi}$ and glass matrix of a red bead from Magoro Hill, an archaeological site in Limpopo Province, South Africa, recalibrate the settlement chronology. J. Mol. Struct. 2012, 1023, 123-127. [CrossRef]

139. Tournié, A.; Prinsloo, L.C.; Colomban, P. Raman classification of glass beads excavated on Mapungubwe hill and K2, two archaeological sites in South Africa. J. Raman Spectrosc. 2011, 43, 532-542. [CrossRef] 
140. Kirmizi, B.; Gokturk, H.; Colomban, P. Colouring Agents in the Pottery Glazes of Western Anatolia: A New Evidence for the Use of Naples Yellow Pigment Variations during the Late Byzantine Period. Achaeometry 2015, 57, 476-496. [CrossRef]

141. Rosi, F.; Miliani, C.; Brunetti, B.G.; Sgamellotti, A.; Grygar, T.; Hradil, D. Raman scattering features of lead pyroantimonate compounds. Part I: XRD and Raman characterization of $\mathrm{Pb}_{2} \mathrm{Sb}_{2} \mathrm{O}_{7}$ doped with tin and zinc. J. Raman Spectrosc. 2009, 40, 107-111. [CrossRef]

142. Rosi, F.; Manuali, V.; Grygar, T.; Bezdicka, P.; Brunetti, B.G.; Sgamellotti, A.; Burgio, L.; Seccaronif, C.; Miliani, C. Raman scattering features of lead pyroantimonate compounds: Implication for the non-invasive identification of yellow pigments on ancient ceramics. Part II. In situ characterisation of Renaissance plates by portable micro-Raman and XRF studies. J. Raman Spectrosc. 2011, 42, 407-414. [CrossRef]

143. Faurel, X.; Vanderperre, A.; Colomban, P. Pink Pigment optimisation by resonance Raman Spectroscopy. J. Raman Spectrosc. 2003, 34, 290-294. [CrossRef]

144. Opper, M.J.; Opper, H. Powdered-glass beads and beads trade in Mauritania. BEADS J. Soc. Bead Res. 1993, 5, 37-54.

145. Babalola, A.B.; McIntosh, S.; Dussubieux, L.; Rehren, T. Ile-Ife and Igbo Olokun in the history of glass in West Africa. Antiquity 2017, 91, 732-750. [CrossRef]

146. Brill, R.H.; Stapleton, C.P. Chemical Analyses of Early Glasses; Corning Museum: New York, NY, USA, 2012; Volume 3.

147. Wedepohl, K.H.; Simon, K.; Kronz, A. Data on 61 chemical elements for the characterization of three major glass compositions in late antiquity and the Middle Ages. Archaeometry 2011, 53, 81-102. [CrossRef]

148. Babalola, A.B.; Rehren, T.; Ige, A.; McIntosh, S. The Glass Making Crucibles from Ile-Ife, SW Nigeria. J. Afr. Archaeol. 2018, 16, 31-59. [CrossRef]

149. Koleini, F.; Colomban, P.; Pikirayi, I. Chronology of Danamonde, Naletale, Gomoremhiko and Zinjanja based on the composition of traded glass beads by pXRF and Raman Spectroscopy. 2019; Submitted for publication.

150. Colomban, P. Rocks as blue, green and black pigments/dyes of glazed pottery and enamelled glass artefactsA review. Eur. J. Mineral. 2013, 25, 863-879. [CrossRef]

151. Gratuze, B.; Soulier, I.; Barrandon, J.N.; Foy, D. De l'origine du cobalt dans les verres. Revue d'archéométrie 1992, 16, 97-108. [CrossRef]

152. Gratuze, B.; Soulier, I.; Blet, M.; Vallauri, L. De l'origine du cobalt: Du verre à la céramique. Revue D'archéométrie 1996, 20, 77-104. [CrossRef]

153. Gronenborn, D. Beads and the emergence of the Islamic slave trade in the southern Chad basin (Nigeria). BEADS J. Soc. Beads Res. 2009, 21, 47-51.

154. Guerrero, S. Venetian glass beads and the slave trade from Liverpool, 1750-1800. BEADS J. Soc. Bead Res. 2010, 22, 52-70.

155. Pallaver, K. A recognized currency in beads: Glass beads as money in 19th century East Africa: The Central Caravan road. In Money in Africa; Catherine, E., Fuller, H., Perkins, J., Eds.; The British Museum: London, UK, 2009; pp. 20-29.

(C) 2019 by the authors. Licensee MDPI, Basel, Switzerland. This article is an open access article distributed under the terms and conditions of the Creative Commons Attribution (CC BY) license (http://creativecommons.org/licenses/by/4.0/). 